US Army Corps

of Engineers ${ }_{\circledast}$

Engineer Research and

Development Center

Regional Sediment Management (RSM) Program

\title{
A Review of RSM Implementation Strategies and Recommendations for Ecosystem Restoration in Tampa Bay, Florida
}

Aubree Hershorin, Tony Ledford, Barbara Nist, Matt Schrader,

May 2019

Clay McCoy, Brenae Martin, and Linda Lillycrop

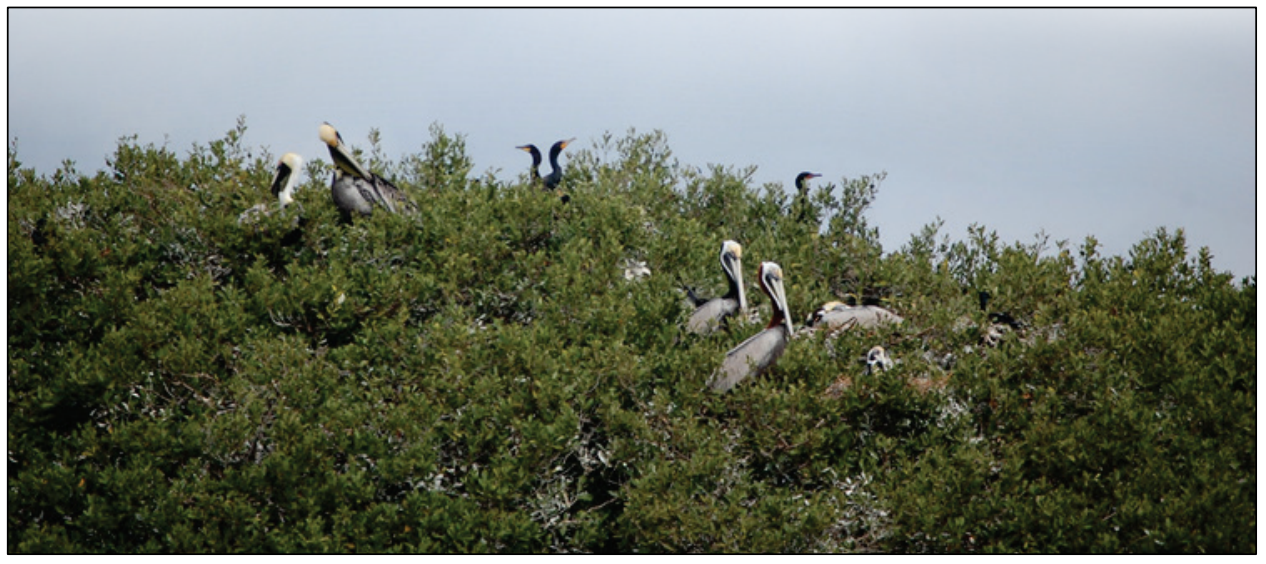


The U.S. Army Engineer Research and Development Center (ERDC) solves the nation's toughest engineering and environmental challenges. ERDC develops innovative solutions in civil and military engineering, geospatial sciences, water resources, and environmental sciences for the Army, the Department of Defense, civilian agencies, and our nation's public good. Find out more at www.erdc.usace.army.mil.

To search for other technical reports published by ERDC, visit the ERDC online library at http://acwc.sdp.sirsi.net/client/default. 


\section{A Review of RSM Implementation Strategies and Recommendations for Ecosystem Restoration in Tampa Bay, Florida}

Aubree Hershorin, Tony Ledford, Barbara Nist, Matt Schrader, Clay McCoy, and Brenae Martin

U.S. Army Engineer District, Jacksonville

701 San Marco Boulevard

Jacksonville, FL 32207-8175

Linda Lillycrop

U.S. Army Engineer Research and Development Center

Coastal and Hydraulics Laboratory

3909 Halls Ferry Road

Vicksburg, MS 39180-6199

Final report

Approved for public release; distribution is unlimited.

Prepared for U.S. Army Corps of Engineers

Washington, DC 20314-1000

Under Project 476925, “Tampa Bay, Florida, Regional Sediment Management” 


\section{Abstract}

Regional Sediment Management (RSM) is a systems approach using best management practices for more efficient and effective use of sediments in coastal, estuarine, and inland environments. The primary RSM objective for this Tampa Bay study is to determine what opportunities exist to beneficially use dredged material for ecosystem restoration and habitat enhancement. A secondary objective is to ensure more efficient use of federal funds by coordinating dredging schedules for navigation and storm damage reduction projects with federal, state, and local authorities. This study met these objectives through collaboration with stakeholders on the technical, social, and cultural components required to combine resources to meet common goals.

The Federal Standard for navigation projects in the Tampa Bay region is either upland disposal or disposal at the Tampa Bay Ocean Dredged Material Disposal Site. This document describes six ecosystem restoration placement strategies: (1) beach nourishment, (2) nearshore placement, (3) dredged hole filling, (4) island creation/stabilization, (5) longshore bars, and (6) thin layer placement. Dredged material from navigation projects throughout Tampa Bay were considered, including Tampa Harbor, Manatee Harbor, St. Petersburg Harbor, and the Gulf Intracoastal Waterway. For each placement strategy, the document outlines the required sediments, volumes, construction methodologies, and estimated costs.

DISCLAIMER: The contents of this report are not to be used for advertising, publication, or promotional purposes. Citation of trade names does not constitute an official endorsement or approval of the use of such commercial products. All product names and trademarks cited are the property of their respective owners. The findings of this report are not to be construed as an official Department of the Army position unless so designated by other authorized documents. 


\section{Contents}

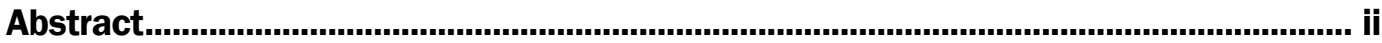

Figures and Tables..................................................................................................................

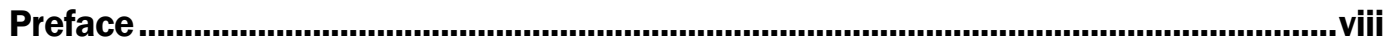

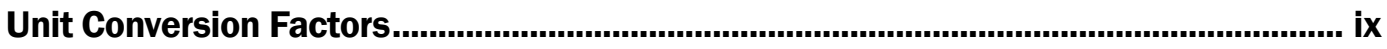

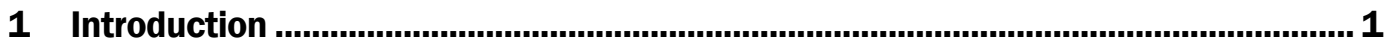

1.1 Regional Sediment Management (RSM) ............................................... 1

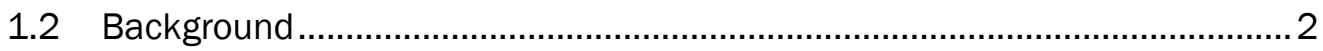

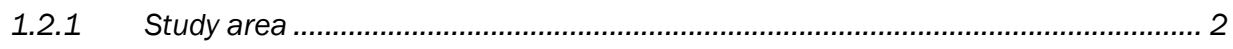

1.2.2 The Federal Standard ..................................................................................... 4

1.2.3 Past RSM strategies and efforts in Tampa Bay.................................................. 4

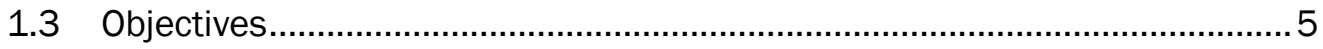

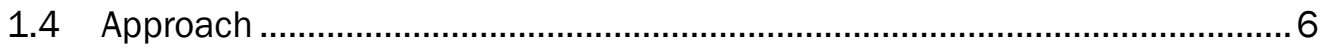

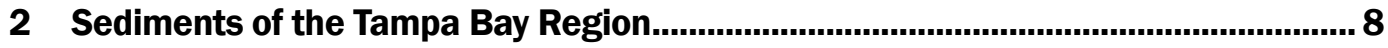

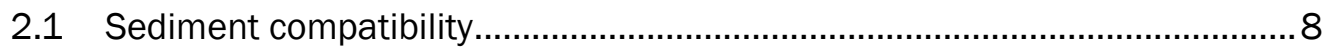

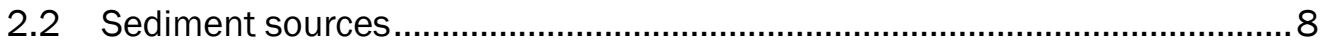

2.2.1 Tampa Harbor Federal Navigation Channel ..................................................... 9

2.2.2 Manatee Harbor ............................................................................................ 12

3 Tampa Bay Sediment Management: Alternative Placement Options......................14

3.1 Upland disposal .....................................................................................

3.2 Ocean Dredged Material Disposal Site (ODMDS) .......................................14

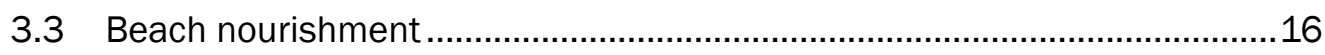

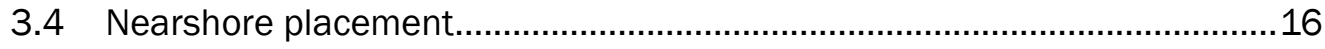

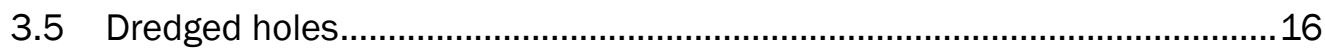

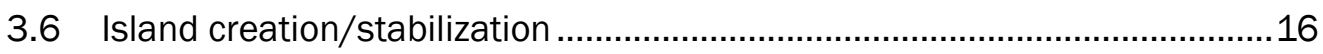

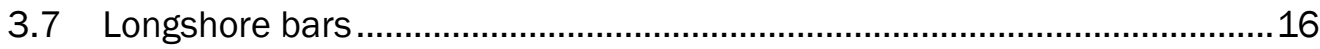

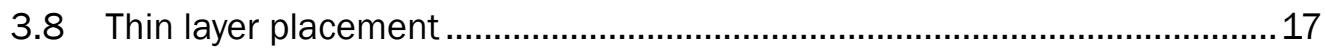

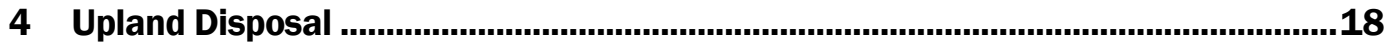

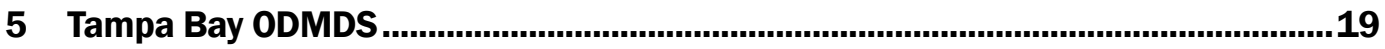

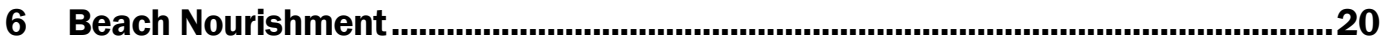

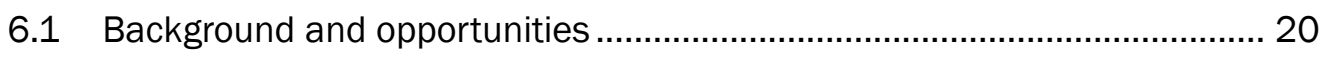

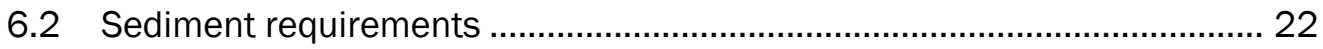

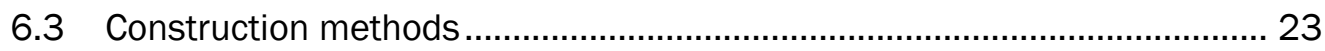

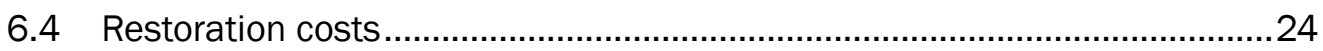

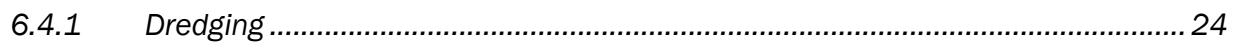

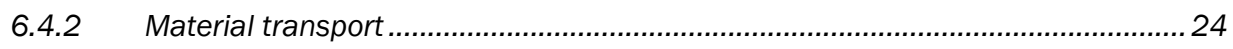




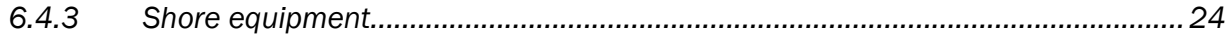

7 Nearshore Placement...............................................................................................25

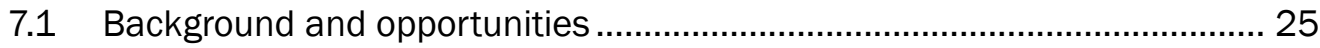

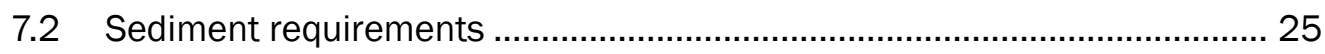

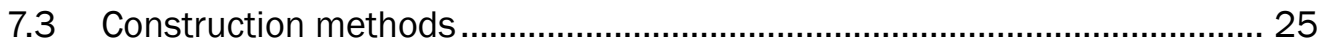

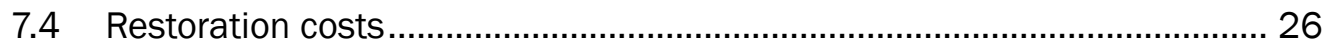

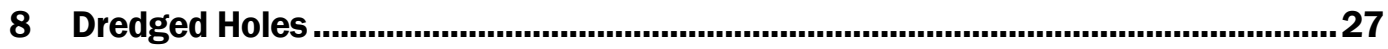

8.1 Background and opportunities ........................................................... 27

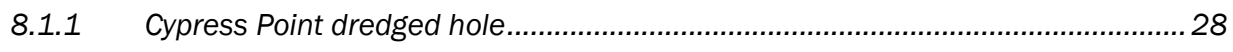

8.1.2 Northeast St. Petersburg Borrow Pit 1.................................................................. 29

8.1.3 Northshore Beach dredged hole ............................................................................. 29

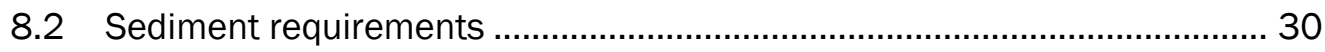

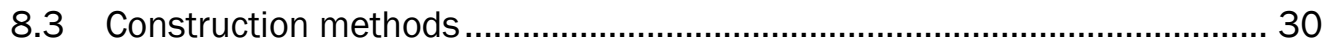

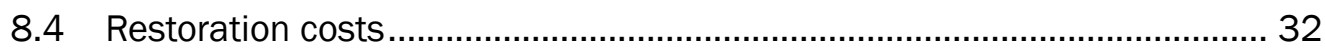

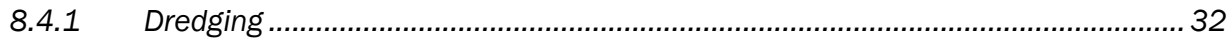

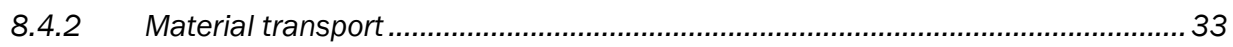

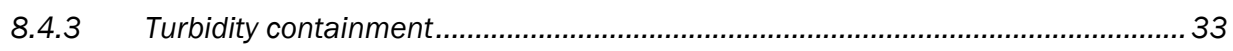

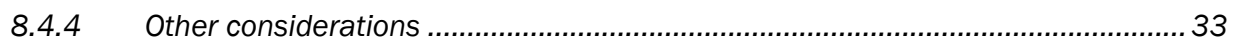

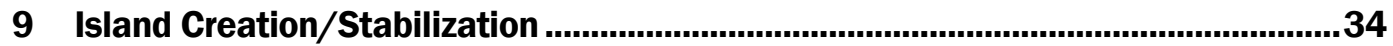

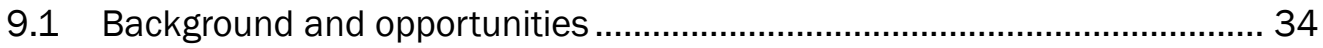

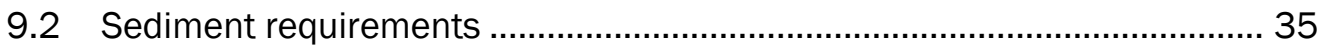

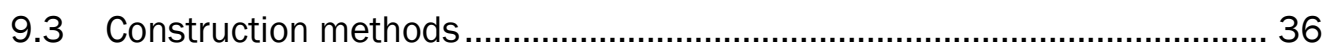

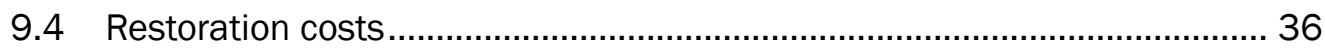

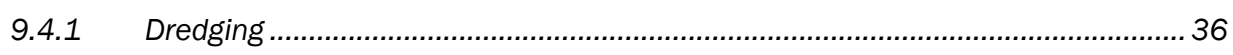

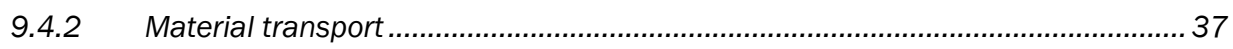

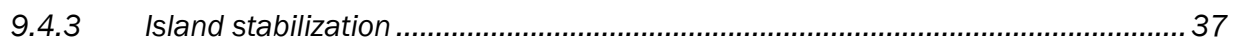

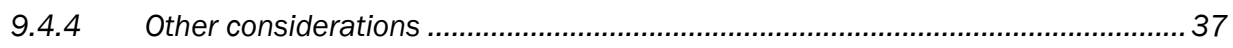

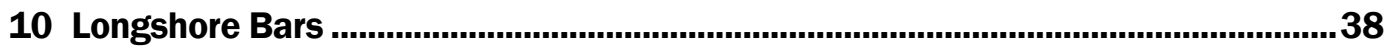

$10.1 \quad$ Background and opportunities....................................................... 38

10.1.1 Tampa Bay Estuary Program (TBEP) pilot project ............................................... 40

10.1.2 Design 1. Medium-sized riprap with a minimum diameter of $12 \mathrm{in.......................4} 41$

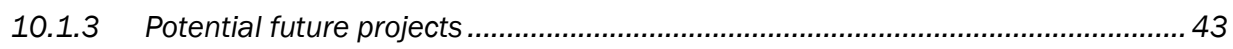

10.2 Sediment requirements ............................................................. 44

10.3 Construction methods................................................................ 44

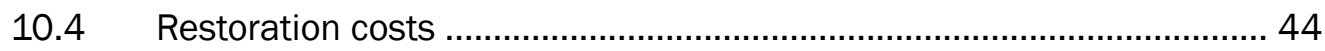

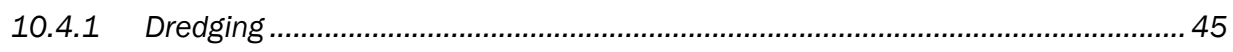

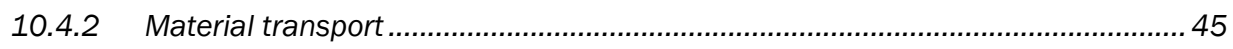

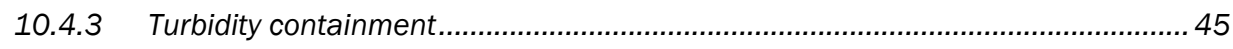

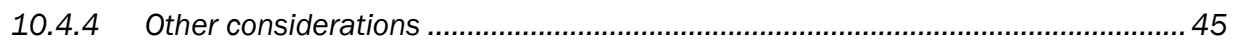

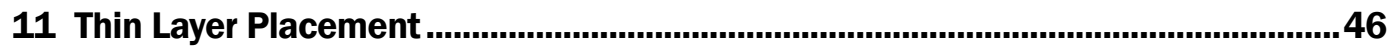

$11.1 \quad$ Background and opportunities.................................................... 46 


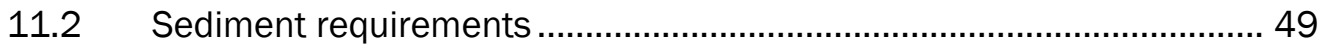

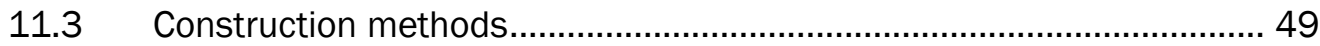

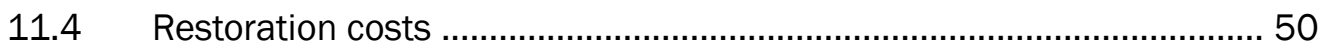

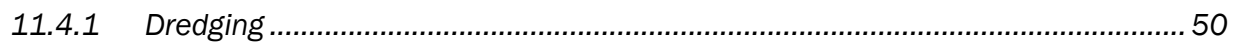

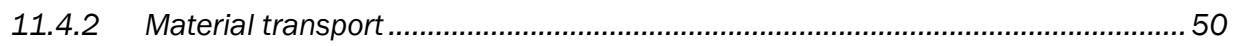

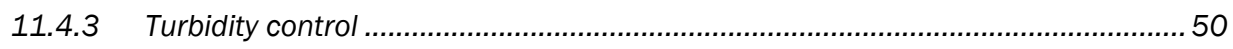

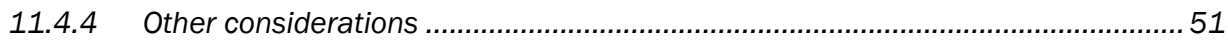

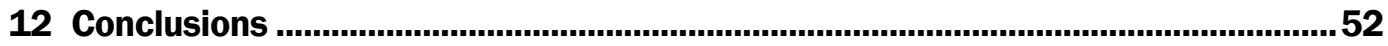

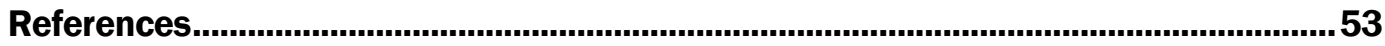

\section{Report Documentation Page}




\section{Figures and Tables}

\section{Figures}

Figure 1-1. Study area noting the locations of all federal projects in the Tampa Bay, Florida, area and the Tampa Ocean Dredged Material Disposal Site (ODMDS).

Figure 2-1. Sediment types from historic dredging data throughout Tampa Bay, including sediment dredged from federal navigation channels (sediment data courtesy of Hillsborough County Environmental Protection Commission).

Figure 2-2. Tampa Harbor Federal Navigation Channel project, including authorized depths of each cut within the harbor

Figure 2-3. Manatee Harbor project map.

Figure 6-1. Beach and nearshore placement options for Tampa Bay navigation projects.

Figure 8-1. Dredged hole management recommendations from TBEP (2005) Technical Publication 04-05 (2006 shown in blue), as well as the locations of the holes in the 2017 TBEP study (shown in orange; report in preparation)..

Figure 9-1. Potential expansion opportunities at Alafia Banks Sanctuary...

Figure 10-1. Graphic depicting longshore bars and seagrass zonation in Tampa Bay (Lewis 2005).

Figure 10-2. Comparison of historical longshore bar location from 1957 and the same location in 1990 in Tampa Bay (Lewis 2005). Loss of longshore bars in Tampa Bay may have led to a loss of seagrass in front of, and behind, the bars.

Figure 10-3. Comparison of historical longshore bar location from 1957 and the same location in 1990 in Tampa Bay (Lewis 2005). Loss of longshore bars in Tampa Bay may have led to a loss of seagrass in front of, and behind, the bars.

Figure 10-4. Photograph of the project area showing each of the four experimental bar designs. From the background to the foreground: 1. Riprap; 2. Jersey highway barriers; 3 . Sand covered with geo-fabric and riprap; and 4. Reef balls. Photograph was taken from the east, facing toward the west.

Figure 10-5. Locations of historic and current (2004) longshore bars in Tampa Bay. The green shows the current extents while the pink indicates the historic extents. Areas in Old Tampa Bay (the northwest portion of the Bay) and Hillsborough Bay (the northeast portion of the Bay) have experienced the most significant longshore bar losses and would be the most appropriate areas in which to focus restoration opportunities.

Figure 11-1. Thin layer placement during the New Jersey Avalon Pilot Project (photo by Chasten and Goldberg 2016).

\section{Tables}

Table 2-1. Maintenance dredging volumes ${ }^{1}$ between 2006 and 2016 from the Tampa Harbor Federal Navigation Channels.

Table 2-2. Maintenance dredging volumes ${ }^{1}$ between 2006 and 2016 from the Manatee Harbor Federal Navigation Channel. 
Table 3-1. Summary of RSM Opportunities in Tampa Bay with associated costs. NOTE: These costs do not include any additional environmental coordination and monitoring costs that may be required as a result of these alternative placement methods. (source: U.S. Army Engineer District, Jacksonville, files). ..... 


\section{Preface}

This study was conducted for Headquarters, U.S. Army Corps of Engineers (HQUSACE), Washington, D.C., under the USACE National Regional Sediment Management (RSM) Program, Project 476925, "Tampa Bay, Florida, Regional Sediment Management.” The USACE National RSM Program Manager was Ms. Linda S. Lillycrop, U.S. Army Engineer Research and Development Center (ERDC), Coastal and Hydraulics Laboratory (CHL), Navigation Division, Coastal Engineering Branch. Mr. Jeffrey A. McKee was the HQUSACE Navigation Business Line Manager overseeing the RSM Program.

The work was performed by the U.S. Army Engineer District, Jacksonville, (SAJ), and by the ERDC CHL Coastal Engineering Branch. Appreciation is extended to Ms. Holly Greening and Mr. Gary Raulerson, Tampa Bay Estuary Program, St. Petersburg, FL, for providing critical review of the technical aspects of this study and final report.

At the time of publication of this technical report, Dr. Jacqueline S. Pettway was Chief, Navigation Division, CHL; Ms. Lauren Dunkin was Chief, Coastal Engineering Branch, CHL; Dr. Katherine Brutsché was USACE National RSM Program Manager; and Mr. Charles E. Wiggins (CHL) was the ERDC Technical Director for Civil Works, and Navigation Research, Development, and Technology Transfer portfolio. The Deputy Director of CHL was Mr. Jeffrey R. Eckstein, and the Director of CHL was Dr. Ty V. Wamsley.

The commander of ERDC was COL Ivan P. Beckman, and the Director of ERDC was Dr. David W. Pittman. 


\section{Unit Conversion Factors}

\begin{tabular}{|l|l|l|}
\hline Multiply & By & To Obtain \\
\hline acres & 0.404687 & hectares \\
\hline cubic yards & 0.76455 & cubic meters \\
\hline cubic yards per year & 0.76455 & cubic meters \\
\hline feet & 30.48 & centimeters \\
\hline inches & 2.54 & centimeters \\
\hline linear feet & 0.3048 & meters \\
\hline miles & 1.609344 & kilometers \\
\hline
\end{tabular}




\section{Introduction}

\subsection{Regional Sediment Management (RSM)}

The U.S. Army Corps of Engineers (USACE) National RSM Program was established in 1999 to take a regional or systems approach to address sediment-related issues and support sustainable solutions across multiple projects (primarily navigation, flood risk management, and ecosystem restoration) in coordination with partnering organizations, governments, and stakeholders. RSM strategies along with the data and knowledge made available through RSM also provide valuable information for emergency management operations. Because sediment-related challenges and their solutions vary in different regions of the nation, regional RSM teams have been established across the nation to address region-specific challenges to managing sediments.

RSM is a philosophy that implements regional and systems approaches to utilize best management practices across multiple projects for more efficient and effective use of sediments in coastal, estuarine, and inland environments. The overarching goal is to achieve short- and long-term sustainable environmental, social, and economic benefits both locally and regionally, increasing benefits while maintaining or reducing costs.

The RSM approach includes multiple components including (1) engagement, communication, and collaboration across entities interested in the management and use of sediments (USACE, federal and non-federal agencies, non-governmental organizations (NGO), states, stakeholders, sponsors, resource agencies, and local communities). This includes participating in or establishing an Interagency Working Group that focuses on sediment management; (2) integration across multiple projects, communities, programs, authorities, funding and other resources, and USACE business lines to allow contributions from all resources to achieve success; (3) sound engineering and science in the application of tools and technologies to understand the region, identify and evaluate RSM strategies, overcome challenges, assist in decision making, and provide adaptive management (Lillycrop et al. 2011).

This RSM technical report documents enacted and potential RSM strategies for the beneficial use of dredged materials in and around Tampa 
Bay, Florida. The strategies were developed during a stakeholder-driven process undertaken by the U.S. Army Engineer District, Jacksonville (SAJ), from January 2016 to February 2017. This technical report includes an overview of the study area, descriptions of the federal projects in the study area and past RSM activities associated with them, summaries from stakeholder meetings, and the strategies developed by the project delivery teams (PDTs). While it may not be possible to immediately implement the strategies provided in this technical report, information is provided to enable their use with approximately 6-months lead time to obtain any additional permits or data that may be required for their implementation.

\subsection{Background}

Tampa Bay has a history of successful RSM efforts, including the beneficial use of dredged material from the federal navigation channels for shore protection, restoration of seagrass habitat, and creation of bird nesting habitat. The beneficial use of navigation maintenance material for shore protection at the Pinellas County Shore Protection Project and on Egmont Key alleviates erosional pressure on these vulnerable shorelines and protects upland assets. As a result, re-nourishment intervals for Pinellas County project can be increased, reducing overall project costs. Navigation material has also been used to restore holes that were previously created by mining of construction material for upland development south of MacDill Air Force Base. Filling holes to the surrounding grade allows seagrasses to reestablish in these areas. Finally, bird nesting habitat was created through placement in a number of ways: (a) the Alafia Bank Bird Sanctuary was created using dredged material from the construction of Tampa Harbor's Alafia Channel; (b) material placed at the north end of Egmont Key hosts thousands of nesting birds; and (c) material placed at the dredged material management areas (DMMAs) deters vegetation growth in the short-term and creates a beach-like habitat for nesting shorebirds.

\subsubsection{Study area}

Tampa Bay is located on the Gulf Coast of Florida and includes portions of three counties: Pinellas, Hillsborough, and Manatee (Figure 1-1). The study area includes Tampa Bay and the coastlines adjacent to the mouth of the Bay where a number of federally authorized USACE projects are located: 
- three deep-draft federal harbors (Tampa Harbor, Manatee Harbor, and St. Petersburg Harbor)

- three shallow draft inlets (Johns Pass, Blind Pass, and Clearwater Pass)

- two federal hurricane and shore protection projects (Pinellas and Manatee counties)

- the Gulf Intracoastal Waterway (GIWW).

Figure 1-1. Study area noting the locations of all federal projects in the Tampa Bay, Florida, area and the Tampa Ocean Dredged Material Disposal Site (ODMDS).

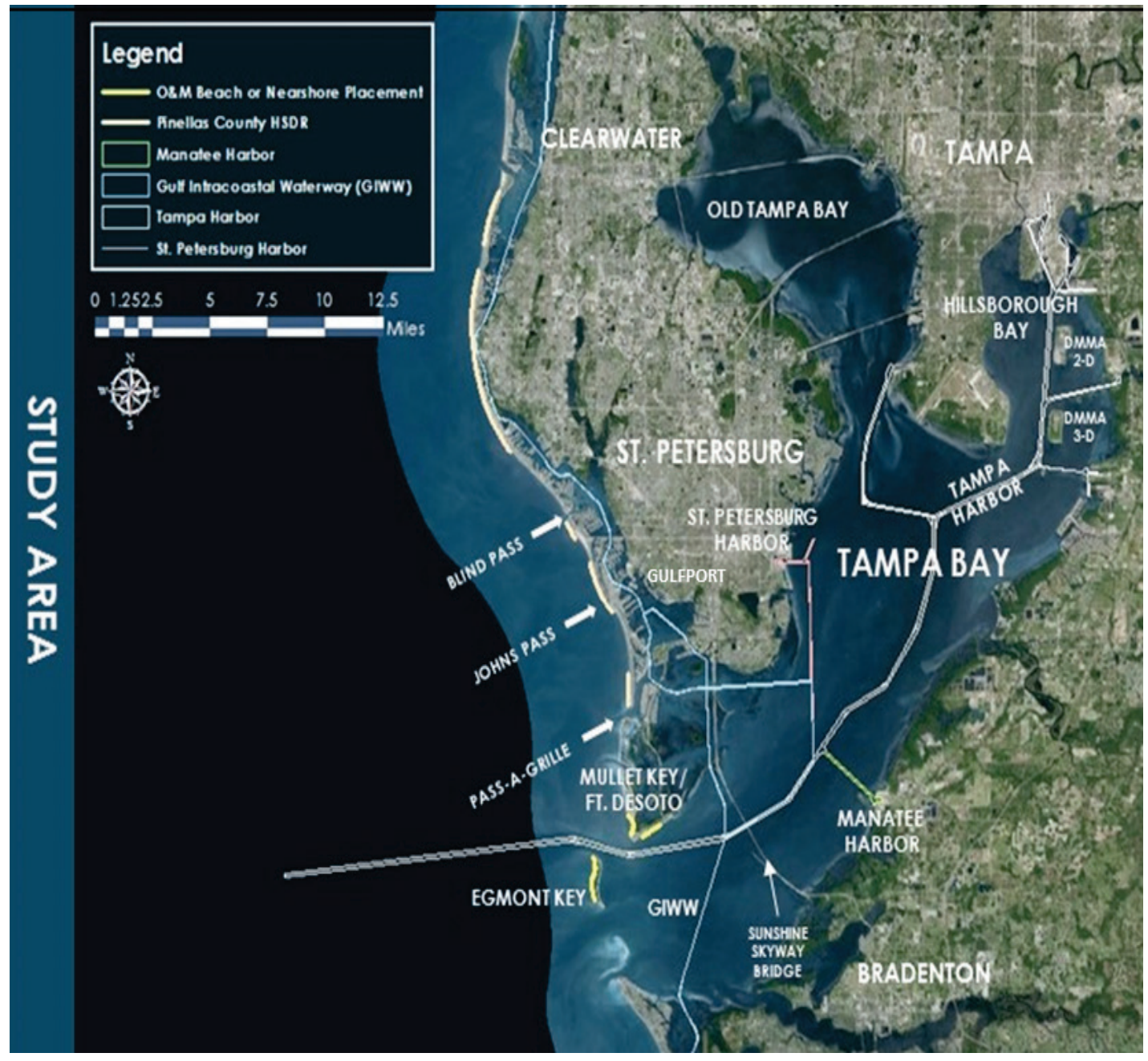

USACE is currently studying the feasibility of providing erosion control measures to assist the City of Gulfport (Figure 1-1) to address flooding concerns at the adjacent Boca Ciega Bay through the Federal Continuing Authorities Program. It is the proximity of these federal and local projects, and their needs for sediment removal or placement, that makes this an ideal area to implement RSM strategies. Section 2.2 of this report provides more information about the federal projects located in the study area. 


\subsubsection{The Federal Standard}

USACE regulations require that navigation projects place dredged material at the location that results in the least cost to the federal government while providing sound engineering practices and meeting environmental standards, which is typically referred to as the "Federal Standard." The Federal Standard is defined in 33 CFR (Code of Federal Regulations), Part 335, Section 335.7, Definitions, which states "Federal Standard means the dredged material disposal alternative or alternatives identified by the Corps which represent the least costly alternatives consistent with sound engineering practices and meeting the environmental standards established by the 404(b)(1) evaluation process or ocean dumping criteria." The Federal Standard is established to (1) protect the federal investment in projects; (2) conserve scarce federal funding to meet the navigation mission; (3) provide a consistent approach across projects; and (4) provide non-federal sponsors an opportunity to pay for additional requirements above and beyond the Federal Standard. The 2016 Water Infrastructure Improvements for the Nation (WIIN) Act (Section 1188, Sense of Congress) also includes language guiding the fate of dredged materials, stating that "open-water disposal of dredged material should be reduced to the maximum extent practicable."

The Federal Standard for navigation projects in the Tampa Bay region is either upland disposal or disposal at the Tampa Bay ODMDS.

\subsubsection{Past RSM strategies and efforts in Tampa Bay}

USACE has implemented RSM strategies in the Tampa Bay area for over 30 years. While not originally intended as beneficial use, the islands created through the placement of dredged material during the initial construction of Tampa Harbor are currently some of the most important shorebird and colonial seabird nesting sites in Florida. Beach-compatible material from Johns Pass and Blind Pass was placed on the beaches downdrift of the inlets rather than disposed offshore or on upland islands as early as the 1980 .

\subsubsection{Dredged hole restoration.}

SAJ has worked with the local stakeholders through the Tampa Bay Regional Planning Council's Agency on Bay Management since the early 2000 s to identify beneficial uses for the maintenance material dredged 
from both Tampa and Manatee Harbors. A multi-agency partnership, the Tampa Bay Estuary Program (TBEP), conducted a dredged hole study that analyzed a number of previously dredged holes throughout the Bay for their habitat value (TBEP 2005). That report provided guidance to agencies on which holes to prioritize for restoration. The report's findings have since been used to restore (or partially restore) two dredged holes in Tampa Bay: MacDill Hole and McKay Bay Dredged Hole. An update to the study will be completed in 2018 .

\subsubsection{Beach and nearshore placement.}

SAJ has successfully placed material from Johns Pass and Blind Pass onto the downdrift beaches that are part of the Pinellas County Shore Protection Project for almost 20 years. SAJ placed maintenance material from the entrance cuts of Tampa Harbor on the beaches at Ft. DeSoto and, more frequently, at Egmont Key. USACE has also occasionally placed smaller volumes of material in the nearshore area of Egmont Key. The most recent placement of dredged material at Egmont Key used material that was finer than the Florida Department of Environmental Protection (FDEP) typically permits. SAJ coordinated extensively with FDEP and the U.S. Fish and Wildlife Service (USFWS) to monitor the project prior to, and following, beach placement at Egmont Key.

\subsection{Objectives}

RSM is a systems-based approach to integrating the management of littoral, estuarine, and riverine sediments to achieve balanced and sustainable solutions to sediment-related needs. The primary RSM objective for the Tampa Bay study area is to beneficially use dredged material for ecosystem restoration and habitat enhancement. A secondary objective is to save federal funds by coordinating dredging schedules for navigation and storm damage reduction projects. These objectives can be reached by coordinating available federal authorities, permitting, and funding, and by collaborating with stakeholders on the technical, social, and cultural components to promote strategies, reach objectives, and combine resources to meet common goals.

This document describes the required sediment types and volumes needed for each restoration strategy, as well as construction methodologies and approximate order-of-magnitude costs for ecosystem restoration alternatives. Dredged material from navigation projects throughout 
Tampa Bay were considered, including Tampa Harbor, Manatee Harbor, St. Petersburg Harbor, and the GIWW.

The ultimate objectives of this report are to describe RSM strategies and put forth recommendations for ecosystem restoration in Tampa Bay, Florida.

\subsection{Approach}

The study approach was to collaborate with stakeholders to identify RSM opportunities and to evaluate the feasibility of these alternatives based on the sediment requirements, construction methods, and restoration costs. The project team included geologists, design engineers, and cost engineers to provide guidance. The team collected data on the sediments found throughout Tampa Bay and researched the sediment characteristics required for the placement alternatives identified. They outlined the possible construction methods for each of the alternatives to determine whether they would vary significantly from standard dredging methods and to identify any innovative methods that may be required to successfully implement sediment placement. Finally, cost engineers priced the components of each placement alternative to provide approximate order-of-magnitude cost estimates for use in determining any differences in cost between the RSM alternatives and the least-cost alternatives.

Collaboration with stakeholders is critical to successful RSM implementation. Stakeholders in the Tampa Bay community include federal, state, and local government agencies; NGOs; and private sector interests. Key participants include Port Tampa Bay, Port Manatee, USFWS, U.S. National Marine Fisheries Service, Southwest Florida Water Management District, Florida Park Service, Environmental Protection Commission of Hillsborough County, Tampa Bay Regional Planning Council, TBEP, Tampa Bay Watch, and Audubon Florida. Many other organizations are also regularly involved in public meetings organized by the Tampa Bay Regional Planning Council, and they play an important role in framing the discussions concerning the Tampa Bay ecosystem.

Building upon the existing groups and regularly occurring meetings that take place in the Tampa Bay region, USACE presented the recommenddations in this document to the Tampa Bay Regional Planning Council at the outset of the study and during the finalization of the selected strategies. Stakeholders framed their priorities to focus on those described in more detail in this report, and their input was invaluable to ensuring the 
strategies selected would be embraced by the local government, agencies, and NGOs who would ultimately be partners in the restoration process.

The study team evaluated the RSM opportunities identified through coordination with stakeholders and agency personnel. The team consisted of experts in geotechnical engineering, cost engineering, and dredging. Team members provided information on the type of sediment required for each RSM opportunity and evaluated the cost-effectiveness of transporting the sediments to the restoration site. Other costs, including distance to the restoration site and turbidity control measures, were considered. The cost estimates provided assist stakeholders who may be interested in obtaining separate funding to pay for costs above the Federal Standard. 


\section{Sediments of the Tampa Bay Region}

\subsection{Sediment compatibility}

Shoaled material dredged from navigation channels ranges from sandy material suitable for beach placement to extremely silty or mucky material. Material obtained from the lower reaches of a watershed is typically sandier while material shoaled in the upper reaches is likely to be siltier. The Environmental Protection Commission of Hillsborough County (EPCHC) conducts sediment sampling throughout Tampa Bay (Figure 21). Data from the $\mathrm{EPCHC}$ are consistent with this understanding as sediments in upper Tampa Bay near the outflow of the Hillsborough River in downtown Tampa contain greater than $50 \%$ fines content by volume.

Restoration projects should attempt to match the sediment used for restoration or creation to the sediments at the placement site. In general, sediments in the channels tend to be similar or slightly siltier to those observed in the surrounding substrates (Figure 2-1). Therefore, restoration

projects using dredged materials should be sited near the dredge location when practicable. Since transporting sediment is expensive, it is also cheaper to place the material in close proximity to the dredge location.

\subsection{Sediment sources}

Tampa Harbor and Manatee Harbor provide the most consistent and highest volumes of maintenance material for restoration opportunities in Tampa Bay. The GIWW, St. Petersburg Harbor, and the various shallow draft inlets also provide sediment opportunities, but their associated volumes are significantly smaller, and they are not dredged as frequently. Sediment availability from Tampa Harbor and Manatee Harbor are described in detail below. Their locations are shown in Figure 1-1, as well as the locations of the smaller sediment sources that are not discussed in this section. 
Figure 2-1. Sediment types from historic dredging data throughout Tampa Bay, including sediment dredged from federal navigation channels (sediment data courtesy of Hillsborough County Environmental Protection Commission).

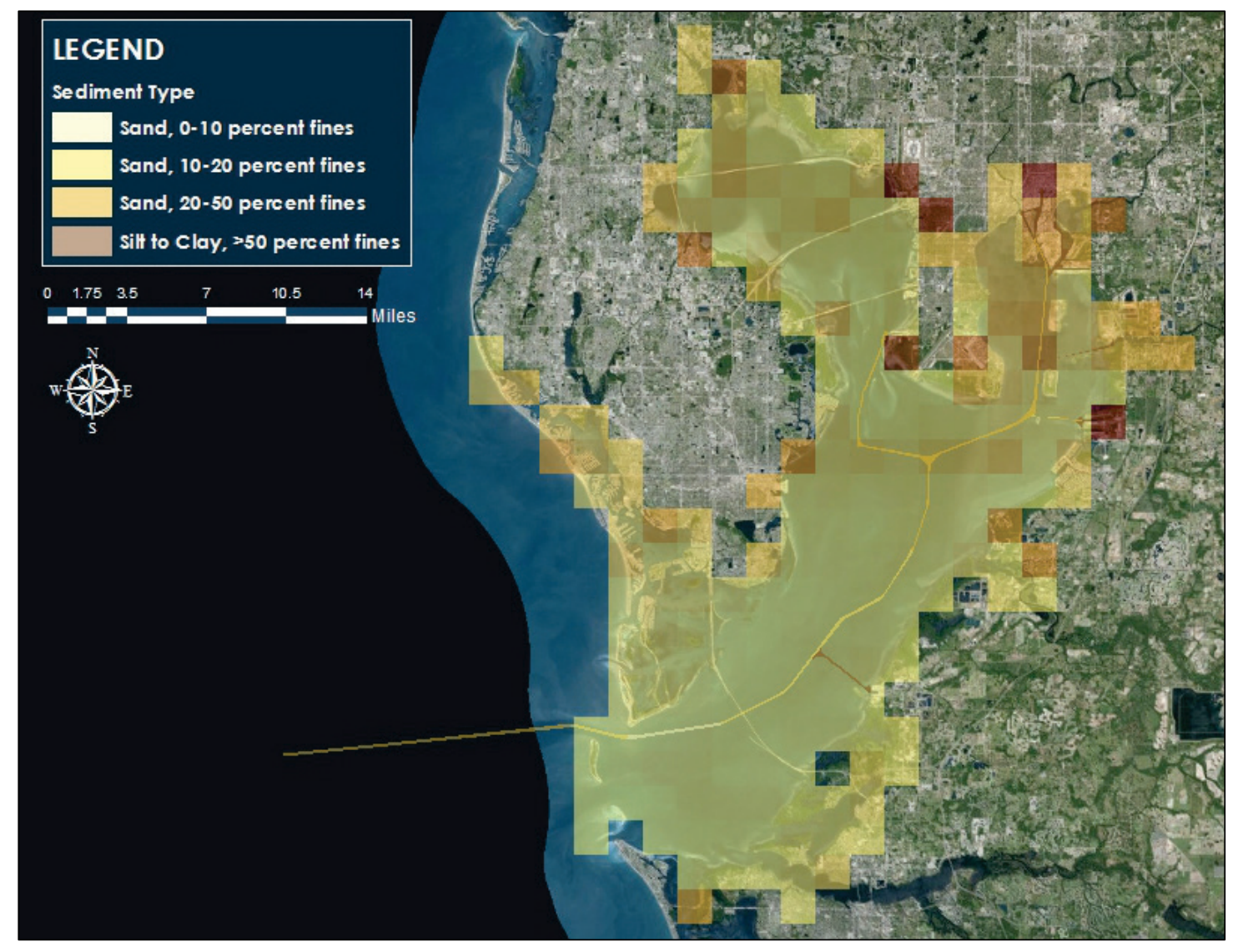

\subsubsection{Tampa Harbor Federal Navigation Channel}

The Tampa Harbor Federal Navigation Channel is composed of 67 miles of channel that extend from the Gulf of Mexico to Port Tampa Bay in downtown Tampa, Florida. This includes 10 miles of channel in the Hillsborough River and 3.6 miles in the Alafia River. Figure 2-2 shows the Tampa Harbor Federal Navigation Channel project, including the authorized depths of each cut within the harbor. 
Figure 2-2. Tampa Harbor Federal Navigation Channel project, including authorized depths of each cut within the harbor.

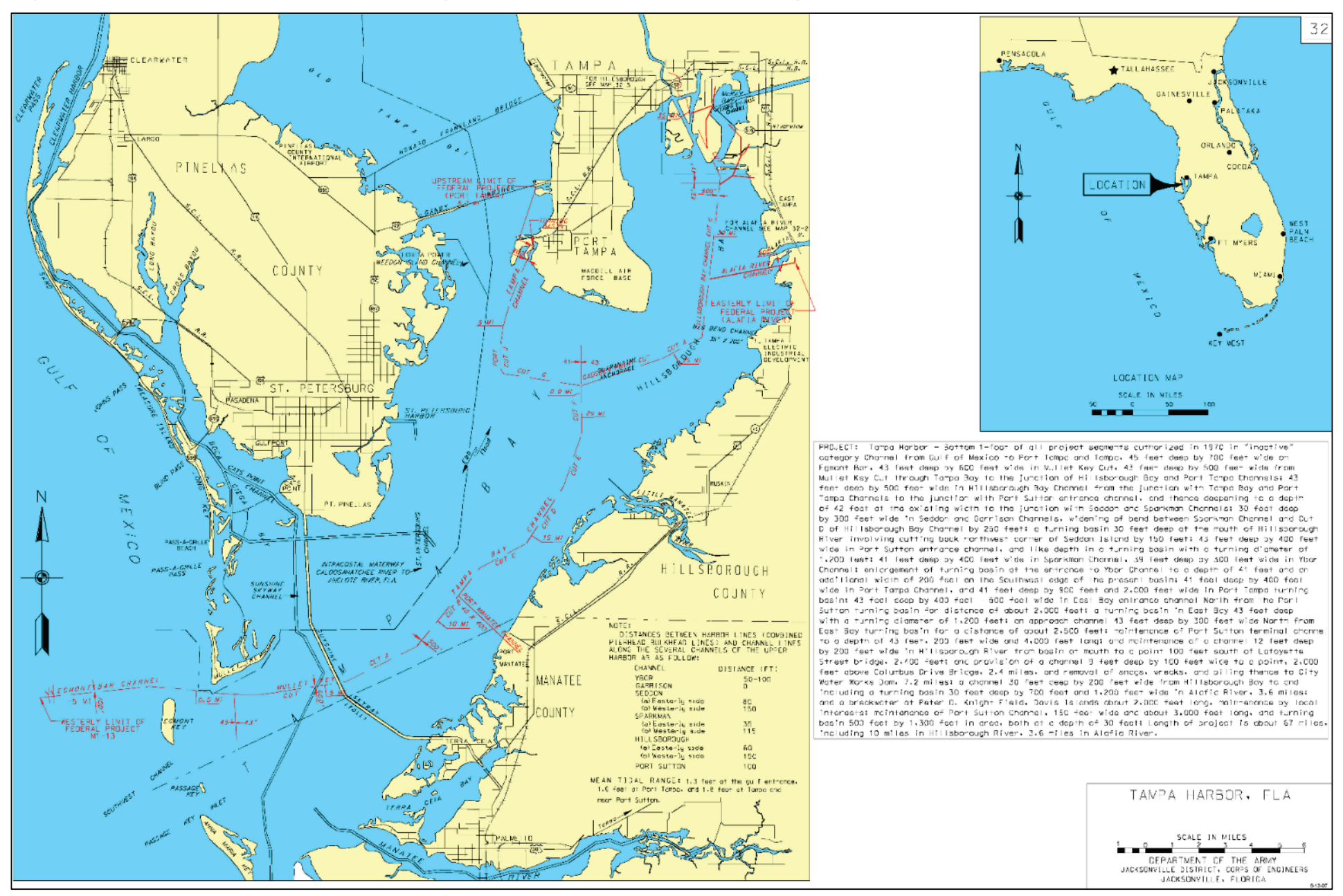


On average, approximately 500,000 cubic yards (cy) of shoaled material are dredged annually from the Tampa Harbor Federal Navigation Channels. The material located from the entrance of the harbor to the Sunshine Skyway Bridge is generally sandy and compatible to place on the beach at Egmont Key or Ft. DeSoto. In the past 10 years, Egmont Key has significantly eroded; therefore, SAJ has preferred to place the material removed from the Tampa Harbor Federal Navigation Channel on the beach at Egmont Key rather than on the beach at Ft. DeSoto for the most recent dredge events.

From the Sunshine Skyway Bridge north to the Upper Cuts (those north of Dredged Material Management Area 2-D), the material tends to be silty sand, with the sediment becoming siltier moving north and westward into the bay. The material dredged from the Upper Cuts is generally silt and more organic than other areas to the south.

Table 2-1 includes the dredging timeframe, dredge location, volume dredged, and placement location for all dredging in Tampa Harbor from 2006 through 2016. Prior to 2006, there were several Tampa Harbor dredging projects that used alternative placement locations. Maintenance material from Cut $\mathrm{G}$ was placed in MacDill Hole in 2000, but there was insufficient material to fully restore this dredged hole. Material from Ybor Channel was placed at Tampa Port Authority's Hookers Point Disposal Area in 2000. Finally, Cockroach Bay Leisey Shell Pit was used for placement of maintenance material from Alafia Channel, Hillsborough Bay Cut A, and Hillsborough Bay Cut C in 2004.

In the past 10 years, SAJ geologists have noted that the material throughout the bay has contained less organic material than was historically observed in the maintenance material dredged from the channels. This could be due to the improved water quality in Tampa Bay over this time period, which has also been the catalyst for significant seagrass recovery in the bay since 2005 (Greening et al. 2011; Sherwood et al. 2017). If this trend continues, the volume of sediment shoaling in the maintained navigation channels may decrease slightly, and the quality of the material dredged may become increasingly sandier. 
Table 2-1. Maintenance dredging volumes ${ }^{1}$ between 2006 and 2016 from the Tampa Harbor Federal Navigation Channels.

\begin{tabular}{|l|l|l|l|}
\hline Dredge Timeframe & Dredge Site & Volume (cy) & Placement Location \\
\hline July - Dec 2006 & Egmont/Mullet Key Cuts & $1,400,000$ & Egmont Key/Ft. DeSoto \\
\hline Feb - Mar 2008 & Alafia River Channel & 260,000 & DA/C Alafia (Mosaic) \\
\hline Nov 2009 - Apr 2010 & Whole Harbor & 330,000 & DMMA 2-D \\
\hline March 2011 & Cuts A, F, and G (TB) & 30,000 & Egmont Key \\
\hline Apr - May 2011 & Cuts A, F, and G (TB) & 250,000 & DMMA 3-D \\
\hline Apr 2012 - Jan 2013 & Cuts A, C, and Alafia & 600,000 & DMMA 2-D \\
\hline Feb - May 2013 & $\begin{array}{l}\text { Upper Cuts (Cuts } \\
\text { C,D,Spark, East Bay, } \\
\text { Port Sutton) }\end{array}$ & 475,000 & DMMA 2-D \\
\hline Nov 2013 - Feb 2014 & $\begin{array}{l}\text { Ybor and Upper } \\
\text { Sparkman }\end{array}$ & 160,000 & DMMA 2-D \\
\hline Nov 2014- Feb 2015 & $\begin{array}{l}\text { Egmont/Mullet Key } \\
\text { Channels }\end{array}$ & 700,000 & Egmont Key \\
\hline Dec 2015 - Feb 2016 & Alafia River Channel & 145,000 & DMMA 3-D \\
\hline Dec 2015 - May 2016 & $\begin{array}{l}\text { Cuts A-K and Gadsden } \\
\text { Point Cut }\end{array}$ & 380,000 & DMMA 3-D \\
\hline Oct 2016 - Feb 2017 & Cuts A, C, and D (HB) & $\begin{array}{l}580,000 \\
(\text { estimated) }\end{array}$ & DMMA 3-D \\
\hline Total & $\begin{array}{l}5,310,000 \\
\text { Annual Volume (cy/yr) }\end{array}$ & 531,000 & \\
\hline
\end{tabular}

${ }^{1}$ These are bid volumes, not final pay volumes, unless otherwise noted.

\subsubsection{Manatee Harbor}

Manatee Harbor (Figure 2-3) comprises approximately 3 miles of channel that extend southeast from Cut B (Tampa Bay) of the Tampa Harbor federal project. Maintenance material from this channel is typically silty sand and has historically been disposed in an upland confined disposal facility. Port Manatee has sold this material in the past to private entities, and it is suitable for dredged hole filling. 
Figure 2-3. Manatee Harbor project map.

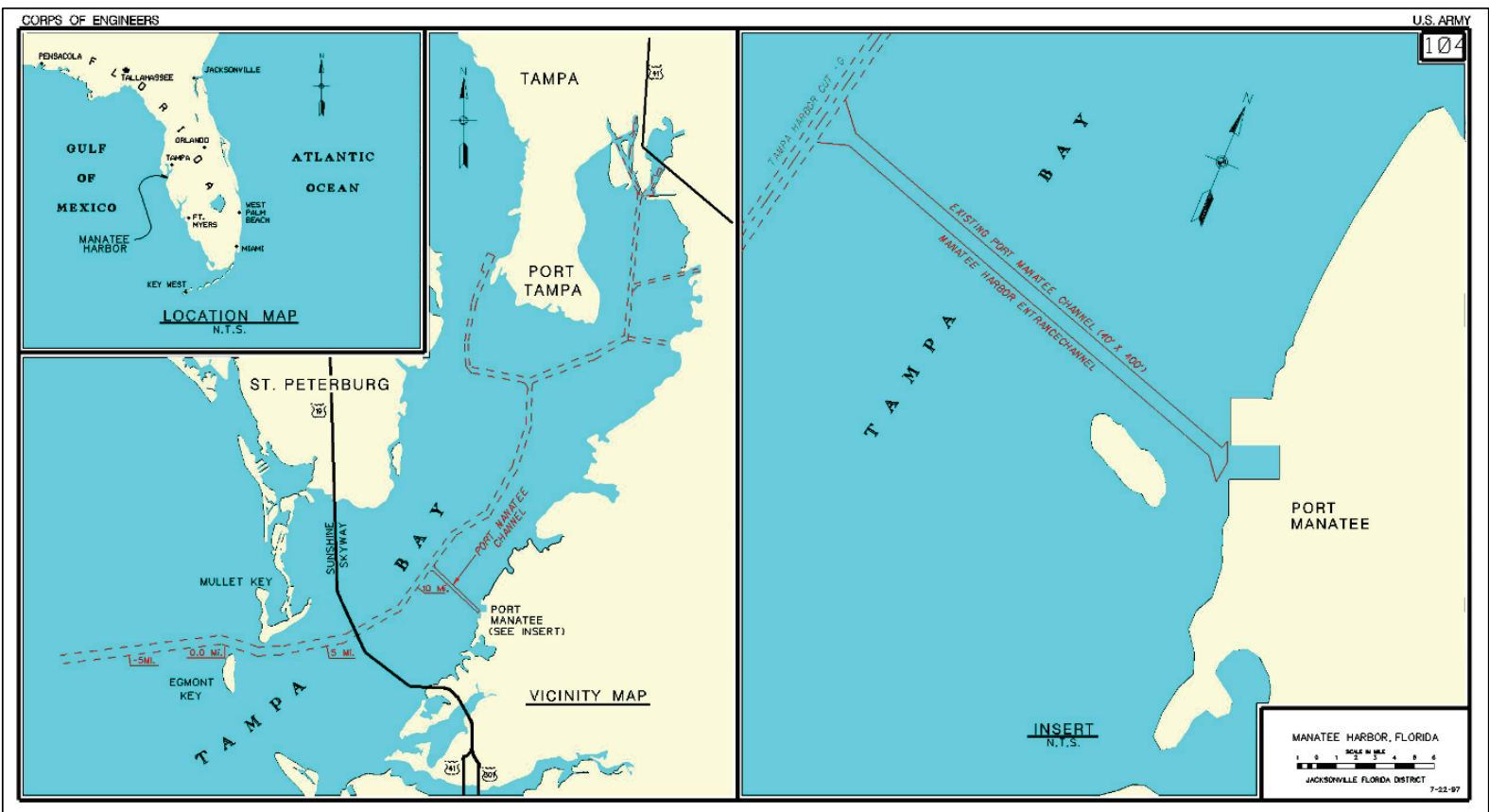

Manatee Harbor typically requires maintenance every 3 to 5 years. Table 2-2 includes the dredging timeframe, dredge location, volume dredged, and placement location for all federal dredging in Manatee Harbor from 2006 through 2016. Port Manatee constructed several projects during this timeframe as well, but information from these efforts is not currently available.

Table 2-2. Maintenance dredging volumes ${ }^{1}$ between 2006 and 2016 from the Manatee Harbor Federal Navigation Channel.

\begin{tabular}{|l|l|l|l|}
\hline Dredge Timeframe & Dredge Site & Volume (cy) & Placement Location \\
\hline Mar - May 2009 & Manatee Harbor O\&M & 150,000 & Manatee Harbor DMMA \\
\hline Nov 2014 - Jan 2015 & Manatee Harbor O\&M & 250,000 & Manatee Harbor DMMA \\
\hline Total & & 400,000 & \\
\hline Annual Volume (cy/yr) & & 40,000 & \\
\hline
\end{tabular}

${ }^{1}$ Bid volumes, not final pay volumes, unless otherwise noted. 


\section{Tampa Bay Sediment Management: Alternative Placement Options}

Successful RSM strategies result from combining authorities, funding, permits, and scheduled work. For Tampa Bay, this results in cost savings while benefitting the region through ecosystem restoration. SAJ personnel often develop these strategies on-the-fly through institutional knowledge. However, having strategies outlined in advance with key information regarding permits and authorities may help to take advantage of all available opportunities and increase the overall efficiency of the USACE mission while continuing to develop strategies for additional benefit to the region. Gaps in federal authority can be identified and targeted for assistance from local sponsors and state agencies. Proactively developing RSM strategies facilitates permitting and various other stakeholder coordination activities that may otherwise prevent an opportunity from being implemented.

The available opportunities for placement of dredged material from Tampa Bay are summarized below, with more details about each option in the following sections. Table 3-1 provides additional information concerning cost associated with each of these RSM opportunities.

\subsection{Upland disposal}

Upland disposal is generally considered the Federal Standard for most of the maintenance material dredged from Tampa and Manatee Harbors.

\subsection{Ocean Dredged Material Disposal Site (ODMDS)}

The placement of rock material at the Tampa ODMDS from the deepening of Tampa Harbor in the 1980 os provided suitable habitat for the establishment of hard bottom resources at the site. Coordination with the resource agencies would be required prior to further placement there to prevent impacts to this resource (USEPA 2009). 
Table 3-1. Summary of RSM Opportunities in Tampa Bay with associated costs. NOTE: These costs do not include any additional environmental coordination and monitoring costs that may be required as a result of these alternative placement methods.

(source: U.S. Army Engineer District, Jacksonville, files).

\begin{tabular}{|c|c|c|c|c|}
\hline RSM OPPORTUNITY & Dredging Costs (per cy) & Transportation Costs & Disposal Costs & Other Costs \\
\hline Upland Disposal & $\begin{array}{l}\$ 15 / \text { cy } \\
\text { (up to } 10 \text { miles) }\end{array}$ & $\begin{array}{l}\$ 1 / \text { cy } \\
\text { (each add'I mile) }\end{array}$ & $\$ 2-\$ 3 /$ cy & N/A \\
\hline \multicolumn{5}{|l|}{ ODMDS $^{1}$} \\
\hline Beach Nourishment & $\begin{array}{l}\$ 10-\$ 27 / \text { cy } \\
\text { (up to } 10 \text { miles) }\end{array}$ & $\begin{array}{l}\$ 1 / \text { cy } \\
\text { (each add'I mile) }\end{array}$ & $\begin{array}{l}\$ 2-\$ 3 / \text { cy } \\
\text { (shore equipment) }\end{array}$ & N/A \\
\hline Nearshore Placement & $\begin{array}{l}\$ 10-\$ 27 / \text { cy } \\
\text { (up to } 10 \text { miles) }\end{array}$ & $\begin{array}{l}\$ 1 / \text { cy } \\
\text { (each add'I mile) }\end{array}$ & $\mathrm{N} / \mathrm{A}$ & N/A \\
\hline Dredged Holes & $\begin{array}{l}\$ 15 / \text { cy } \\
\text { (up to } 10 \text { miles) }\end{array}$ & $\begin{array}{l}\$ 1 / \text { cy } \\
\text { (each add'I mile) }\end{array}$ & $\begin{array}{l}\$ 11 / \text { cy or } \$ 58 / \text { perimeter } \\
\text { per linear (lin) foot ( } \mathrm{ft} \text { ) } \\
\text { (pyramid of three hay bales in the water - } \$ 8 \text { per } \\
\text { lin ft; turbidity curtains - } \$ 120 \text { per lin } \mathrm{ft} \text { ) }\end{array}$ & $\begin{array}{l}\$ 150,000 \text { per location } \\
\text { (additional/interim mobilization) } \\
\text { Remote holes or holes surrounded by SAV would } \\
\text { increase costs }\end{array}$ \\
\hline $\begin{array}{l}\text { Island Creation/ } \\
\text { Stabilization }\end{array}$ & $\begin{array}{l}\$ 15 / \text { cy } \\
\text { (up to } 10 \text { miles) }\end{array}$ & $\begin{array}{l}\$ 1 / \text { cy } \\
\text { (each add'I mile) }\end{array}$ & $\begin{array}{l}\$ 21 / \text { cy } \\
\text { (geotube or riprap perimeter) }\end{array}$ & $\begin{array}{l}\$ 150,000 \text { per location } \\
\text { (additional/interim mobilization). } \\
\text { Costs decrease with increased island } \\
\text { size/quantity of material placed }\end{array}$ \\
\hline Longshore Bars & $\begin{array}{l}\$ 15 / \text { cy } \\
\text { (up to } 10 \text { miles) }\end{array}$ & $\begin{array}{l}\$ 1 / \text { cy } \\
\text { (each add'I mile) }\end{array}$ & $\begin{array}{l}\$ 58 / \text { cy or } \$ 128 / \text { perimeter per lin } \mathrm{ft} \\
\text { (pyramid of three hay bales in the water - } \$ 8 \text { per } \\
\text { lin } \mathrm{ft} \text {; turbidity curtains - } \$ 120 \text { per linear } \mathrm{ft} \text { ) }\end{array}$ & $\begin{array}{l}\$ 150,000 \text { per location } \\
\text { (additional mobilization) } \\
\$ 10-\$ 20 / \text { cy } \\
\text { (add'l cost due to intricate placement and low } \\
\text { volume of fill relative to perimeter) }\end{array}$ \\
\hline Thin Layer Placement & $\begin{array}{l}\$ 15 / \text { cy } \\
\text { (up to } 10 \text { miles) }\end{array}$ & $\begin{array}{l}\$ 1 / \text { cy } \\
\text { (each add'I mile) }\end{array}$ & $\begin{array}{l}\$ 38 / \text { cy or } \$ 53 / \text { perimeter } \\
\text { per lin } \mathrm{ft} \\
\text { (one level of hay bales in the water and turbidity } \\
\text { curtains) }\end{array}$ & $\begin{array}{l}\$ 150,000 \text { per location } \\
\text { (additional/interim mobilization) }\end{array}$ \\
\hline
\end{tabular}

${ }^{1}$ No placement has occurred at the ODMDS since the 1980s. Coordination with resource agencies would be necessary prior to further placement. 


\subsection{Beach nourishment}

Beach nourishment at Egmont Key, Fort DeSoto, and the Pinellas County beaches combats coastal erosion while being a relatively cost-effective placement opportunity. The need for land-based equipment increases costs over nearshore placement, but the associated restoration benefit is substantial.

\subsection{Nearshore placement}

Nearshore placement adjacent to any of the Hillsborough County (Egmont Key) or Pinellas County beaches is an appropriate placement option for material that is too silty for beach placement. As long as it is placed within the sediment sharing system, material placed in the nearshore region will aid in preventing erosion on the adjacent beach. A portion of the material placed in the nearshore is generally expected to move onshore through wave action, depending on the local wave climate. As it does not require shore-based equipment, it is extremely cost effective.

\subsection{Dredged holes}

Dredged holes created for the purpose of obtaining construction material are scattered throughout Tampa Bay. While some provide valuable fisheries habitat, others experience poor water quality and would benefit from restoration. It can be difficult for dredge equipment to access some dredged holes, and turbidity impacts to adjacent seagrasses can be a concern.

\subsection{Island creation/stabilization}

Uninhabited islands in Tampa Bay provide valuable habitat for nesting shorebirds, seabirds, and wading birds. Dredged material (especially from new construction projects) could be used to create new islands and expand existing islands. Turbidity controls are required, especially if maintenance material were used for the work.

\subsection{Longshore bars}

Restoring longshore bars in the Bay could positively impact seagrass habitats in areas impacted by increased wave climate. This is the most expensive option due to the linear nature of placement and the turbidity control requirements. 


\subsection{Thin layer placement}

Thin layer placement involves discharging the material as a slurry onto marsh habitats experiencing lower substrates due to sea level rise or subsidence. Material is typically spread in thicknesses of 6 to 8 inches (in.) to avoid smothering the existing vegetation. Vegetation generally recovers in 1 to 2 years. Mobile Bay and the Columbia River Basin have also successfully implemented subtidal thin layer placement applications. Table 3-1 provides additional information pertaining to the costs associated with each of the opportunities for RSM placement in Tampa Bay. 


\section{Upland Disposal}

USACE traditionally disposes dredged material from Tampa Harbor at DMMA 3-D, located in Hillsborough Bay. This is typically considered to be the Federal Standard for the Tampa Harbor Federal Navigation Project. Typical dredging cost with disposal at DMMA 3-D averages approximately $\$ 18 /$ cy for dredging and transport of material up to 10 miles from the dredge site to DMMA 3-D. Disposal of material in DMMA 3-D is typically not a separable cost from the dredging work. However, for discussion purposes, this price could be assumed to be $\$ 2-\$ 3 /$ cy of the total $\$ 18 / \mathrm{cy}$ unit price. This does not account for mobilization and demobilization cost or any associated costs (such as environmental monitoring). An additional cost of $\$ 1 /$ cy is considered a reasonable assumption for each additional mile of material transport between 10 and 20 miles. Any costs of RSM alternatives over those described here may be required to have a costshare partner for consideration as a feasible alternative to DMMA 3-D disposal, which is the least-cost disposal option and the Federal Standard for placement of materials from Tampa Harbor.

The costs associated with maintenance and expansion of DMMA 3-D are not considered in the costs described above for disposal at DMMA 3-D. As continued disposal at DMMA 3-D would eventually require further expansion or the development of alternative disposal areas, such expansion or development costs should be factored into the calculations when determining the least-cost disposal option. 


\section{Tampa Bay ODMDS}

ODMDS locations are typically in federal waters. In the Gulf of Mexico, the delineation of federal waters begins 9 miles offshore. Dredged material that does not meet FDEP standards for beach or nearshore placement (see Sections 6.2 and 7.2) is typically disposed in an upland DMMA or deposited offshore in an ODMDS. USACE evaluates dredged material intended for ocean disposal for compliance with physical, chemical, and toxicological parameters as set forth by Section 103 of the Marine Protection, Research, and Sanctuaries Act (MPRSA) (U.S. Congress 1972), also known as the Ocean Dumping Act. The U.S. Environmental Protection Agency provides a concurrence letter, which is required under Section 103 of MPRSA.

Due to the distance of the ODMDS from the dredge areas, there are significant fuel costs associated with placement in the ODMDS. 


\section{Beach Nourishment}

\subsection{Background and opportunities}

USACE projects have historically placed beach quality material at Egmont Key and Ft. DeSoto (Figure 6-1). As both of these locations are publicly owned and almost completely undeveloped, it is difficult to obtain funding for traditional beach restoration projects intended to protect upland infrastructure in these locations. While both islands are relatively undeveloped, they both are culturally and historically important. Figure 6-1 also shows other beach nourishment options for Tampa Bay federal navigation projects.

Figure 6-1. Beach and nearshore placement options for Tampa Bay navigation projects.

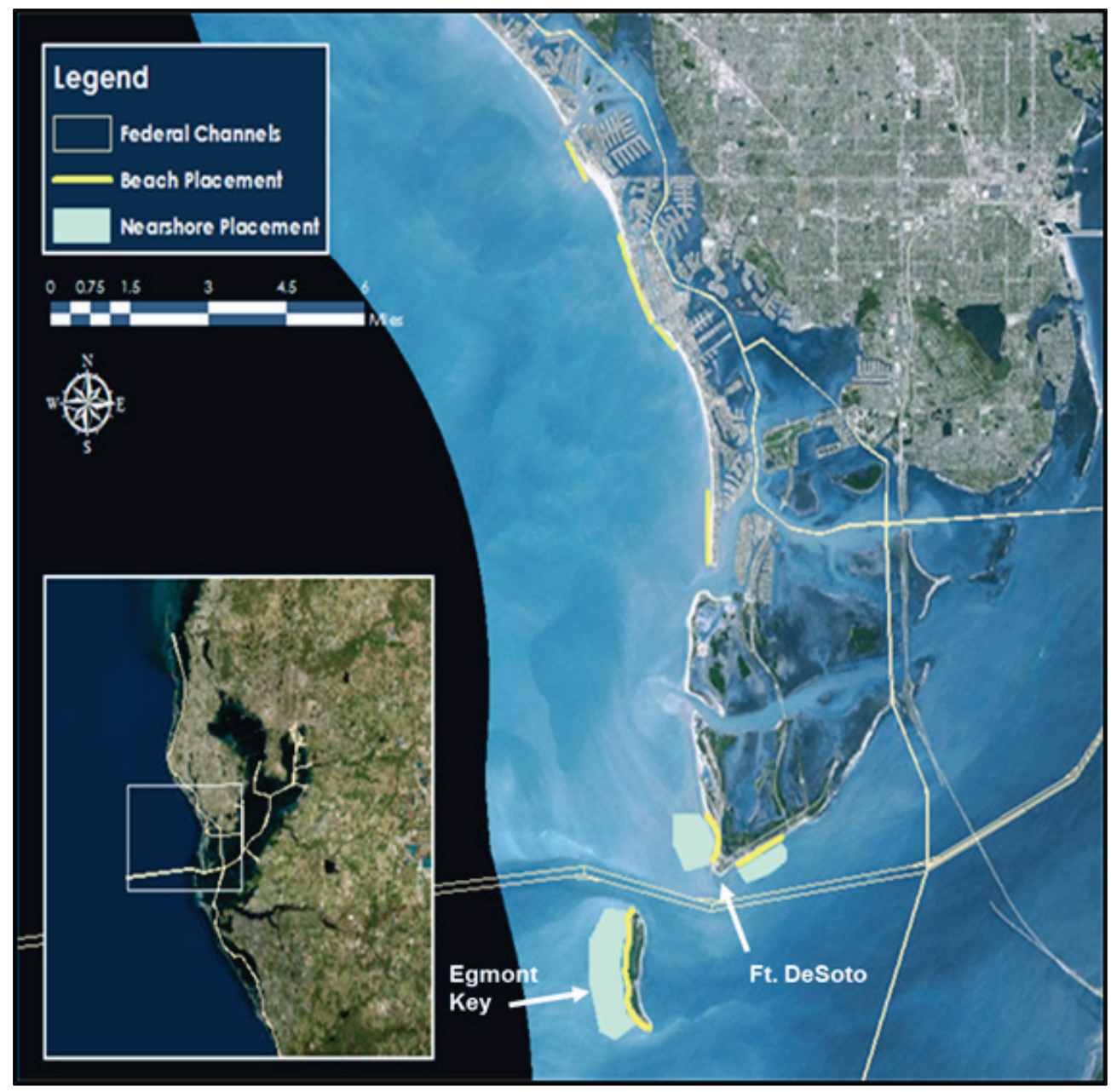


The first lighthouse on the Gulf Coast of Florida was built on Egmont Key in 1848. At that time, Egmont Key was over twice as wide as it is today. In the 1850 s, the island was used to hold Seminole Indians prior to transport to Arkansas and Oklahoma. During the Civil War, it was used as a refuge for Union sympathizers and housed a military prison. Egmont Key is home to Fort Dade, which was first constructed in 1898 to protect Tampa during the Spanish/American War. While the Fort was never attacked, it was home to 300 residents by 1910 , and the small town included a narrow gauge railroad, brick streets, an electric generating plant, and 70 buildings.

Fort Dade was used as a training center for National Guard Artillery Units. It was briefly deactivated following World War I but reactivated during World War II as a harbor patrol station and an ammunition storage facility. The island is currently managed as a national wildlife refuge by the USFWS. Egmont Key State Park was established by the State of Florida in 1989. The U.S. Coast Guard (USCG) still operates the lighthouse on 55 acres at the northern end of the island, and the Tampa Bay Pilots Association leases 10 acres of land on the east side of the island for Tampa Bay pilots' use during their shifts.

Fort DeSoto is a historic site located on Mullet Key north of Egmont Key. This island was first occupied by Native Americans and later explored by Hernando De Soto. Mullet Key was surveyed by U.S. Army engineers in 1849 , and it was recommended as a site for coastal defenses at that time. However, no fortifications were built at Mullet Key during the Civil War. This prompted Tampa to demand military defenses for Tampa Bay, and construction on the island began in 1898 to include a 275 -foot (ft)-long wharf extending into Tampa Bay, offices, and quarters for workers. In 1899, the Secretary of the Treasury transferred 271 acres of the eastern end of Mullet Key to his department for quarantine purposes. A narrowgauge railway ran between the wharf and a construction plant. In 1900, the military installation was named Fort DeSoto after the Spanish explorer Hernando De Soto. The fort became an active battery with massive mortar emplacements, and approximately 125 troops were stationed there. In 1907, the Florida State Troops and the National Guard of Florida also participated in training exercises at the fort. Soon after that time, the fort became inactive, and the area was used as a hunting preserve for Fort Dade (on Egmont Key). During World War II, the fort was serving only as a bombing range. In 1948, Pinellas County bought the island from the U.S. Government. At this time, 26 of the 29 original 
post buildings were still standing. The purchase included 271 acres of land, plus an additional 613 acres of land that the military had occupied. Fort De Soto Park was established in 1963, and the fort was listed on the National Register of Historic Places in 1967. The park is currently operated by Pinellas County and comprises five offshore keys: Madelaine Key, St. Jean Key, St. Christopher Key, Bonne Fortune Key, and Mullet Key (the main island).

\subsection{Sediment requirements}

FDEP regulations provide guidelines on the quality of sediment that can be placed on the beach or in the nearshore region to ensure that the material placed in Florida's coastal system is compatible with the natural ecosystem. Sediment used for beach placement must have similar characteristics (grain size, silt content, color, etc.) to the material found historically on the targeted beach. While the standards are slightly more relaxed for materials obtained from navigation channels to encourage beneficial use of dredged materials, the majority of the material dredged from the Tampa Bay area channels does not meet the requirements for beach placement.

FDEP determines sediment compatibility in their permit process and places limits on the percent silt (fines passing the \#230 U.S. Standard sieve) that can be placed in state waters and on shorelines. Sand with up to $5 \%$ fines by volume can be placed for the purpose of beach nourishment (F.A.C. 62B-41.007). Up to 10\% fines by volume can be placed if the sand has been dredged for navigation purposes and is being beneficially used by placing it on a beach. Material dredged from navigation channels and placed in the nearshore can contain up to $20 \%$ fines by volume.

In 2014-2015, USACE coordinated with resource agencies in the Tampa Bay area to allow for a trial of beach placement of maintenance material with an average of $28 \%$ fines by volume content. Initial data indicate that there was minimal impact to nesting shorebirds, and monitoring is still ongoing to identify if there was any effect on sea turtle nesting.

Based on FDEP rules and the 2014-2015 placement event, USACE recommends that sediment used for beach placement should contain less than 20\% fines content (10\% per Florida rule). Tampa Harbor channel 
cuts located west and south of the Sunshine Skyway Bridge have historically produced material of 10\% fines by volume (Figure 1-1).

\subsection{Construction methods}

Beach nourishment widens a beach and advances the shoreline seaward. Dredged material from navigation channels is typically placed on the beach but can also be placed in a dune system. After placement, the material is redistributed gradually by natural coastal processes.

Hopper, mechanical, and cutter-suction dredges are capable of placing dredged materials on the beaches of Egmont Key and Mullet Key. The most recent maintenance dredging of Egmont Cut 1, Egmont Cut 2, and Mullet Key Cut was performed in 2014 and 2015 by two hopper dredges pumping the beneficial use material through dredge pipes onto Egmont Key. There, dredged material was first used to create temporary dikes along the beach parallel with the shore. This allows the slurry material to be discharged behind the dikes into the beach template, which provides settlement time for fines and minimizes material losses due to the wave climate along the shoreline. Additionally, this construction methodology minimizes turbidity in the nearshore zone. After placement behind the shore-parallel dike, shore construction equipment such as bulldozers and other support equipment spread the slurried material to create the specified template. This construction process is typical of most beach nourishment projects.

In 2012, several hundred thousand cubic yards of material were placed in the nearshore of Egmont Key from the Gulf Intracoastal Waterway. This material was bottom-dumped from the small (512 cy) USACE hopper dredge Murden .

In 2010, a similar volume of material (200,000-300,000 cy) was placed on Egmont Key from Tampa Harbor Cut A. This maintenance material was dredged by a clamshell dredge, hauled in scow barges, and unloaded by a hydraulic excavator on a barge. The hydraulic excavator placed buckets of material into an unloader, which created a slurry that was then pumped strategically onshore and spread by shore equipment, as discussed above. 


\subsection{Restoration costs}

The beach nourishment construction components that incur costs to the project are described below, as well as their associated cost per unit of measure. Based on the specifics of a proposed project, the items can be combined to calculate the anticipated cost of placing material from any dredged location on the beach.

\subsubsection{Dredging}

Dredging costs can vary dramatically depending on the volume placed, the distance the material is transported, the type of material dredged, and the location of dredging. Historically, prices for beach nourishment at Egmont Key have generally ranged from $\$ 10 /$ cy to $\$ 27 /$ cy of material placed, which includes transportation up to approximately 10 miles. The unit price is more expensive for contracts with less available quantities to be dredged. This estimated cost does not include any mobilization or demobilization costs, or any other associated work items.

- COST: $\$ 10$ to $\$ 27 /$ cy of material

\subsubsection{Material transport}

The price associated with the transport of the dredged material varies based on the method of transport (e.g., pipeline, hopper dredge, or scow barges). Typically, pipeline dredges are not economical at distances over 5 miles, and most hauling distances in the harbor for other dredging operations are less than 10 miles. Assuming a dredging operation similar to what has historically been used at Egmont, hauling material any additional distance beyond 10 miles could be quantified as an additional $\$ 1 /$ cy per added mile.

- COST: $\$ 1 /$ cy/mile (over 10 miles)

\subsubsection{Shore equipment}

Shore equipment associated with beach nourishment is included in the unit prices above for dredging. This cost is typically $\$ 2-\$ 3 /$ cy for standard placement and is not usually a separable cost element bid by contractors. However, this cost was separated out for comparison purposes.

- COST: $\$ 2$ to $\$ 3 /$ cy 


\section{Nearshore Placement}

\subsection{Background and opportunities}

As mentioned previously, the FDEP sand rule regulations generally require that maintenance material placed on the beach contain less than $10 \%$ fines. When material is anticipated to have a higher fines content (up to $20 \%$ fines), nearshore placement is an option that keeps the sediment in the sand sharing system and provides benefit to adjacent beaches. In addition, there are occasionally times when maintenance dredging is necessary, and the required equipment to place material on the beach cannot be acquired or afforded. For instance, the USACE hopper dredge Murden has bottom-dump capabilities but cannot offload material. In 2012, the Murden dredged the GIWW and was able to place the material in the nearshore of Egmont Key. While material placed in the nearshore does not have the immediate storm protection and aesthetic benefits of material placed directly on the beach, it is a valuable option to have available for projects where beach placement is not viable. Studies indicate that intertidal communities and subtidal communities respond similarly to dredged material placement, and the magnitude of disturbance is dependent upon site-specific aspects of the activity (Bolam et al. 2006). Locations where nearshore placement is appropriate in the Tampa Bay region are shown in Figure 6-1.

\subsection{Sediment requirements}

Per FDEP regulations, sediment is required to contain less than 20\% fines to be placed in the nearshore environment.

\subsection{Construction methods}

In most cases, nearshore placement is most efficiently completed by hopper dredges. Hopper dredges are capable of depositing material by opening large doors on the bottom of the vessel to release the material. In some areas, the efficiency of this can be impacted by shallow depths that require the hopper dredge to be light loaded. In many areas along the Gulf Coast of Florida, bottom dumping the material is not a viable option due to the shallow shoreline depths as compared to the East Coast of Florida. Similarly, nearshore placement using a hopper dredge along the Pinellas County and Hillsborough County shorelines is generally not an option and 
must be completed using a cutter suction dredge or clamshell dredge with a hydraulic unloader.

\subsection{Restoration costs}

No historical contract cost data are currently available for nearshore placement construction along the Gulf Coast of Florida. The costs associated with beach placement outlined above are reasonable to use as an estimate for nearshore placement. There are likely to be inefficiencies associated with placing material in the shallow nearshore areas of Tampa Bay that would increase costs; however, the cost savings of not requiring shore equipment to spread material on the beach would offset this additional cost. 


\section{Dredged Holes}

\subsection{Background and opportunities}

Seagrasses are found in a variety of substrates throughout Tampa Bay. During the development of Tampa Bay, upland development was often created from wetlands or open water with the use of material from Tampa Bay. The areas dredged were typically close to the area being filled and historically supported seagrass habitats. The resulting dredged holes are located throughout the Bay and are of various sizes and depths, but they generally remain too deep to support seagrass growth. Many factors influence management decisions about dredged holes in Tampa Bay. For example, the water and sediment quality is important for supporting aquatic species, from microscopic organisms to large fish. The type and number of fish and invertebrates inhabiting dredged holes and surrounding areas are indicators of the habitat value the hole provides. When the hole is anoxic or has other characteristics that limit its habitat value, it is considered to have a higher priority for restoration. Restoration typically involves filling the hole to the surrounding water depths and planting seagrass at the newly restored site.

The TBEP studied 11 dredged holes to determine whether it would be ecologically beneficial to restore the holes or if they were providing habitat value and should remain unrestored. The holes were selected based on their location, proximity to available fill material, perceived habitat value, proximity to other important habitats, current use by commercial and recreational fishermen, and the feasibility of restoration. The study found that restoration of four of the holes through complete or partial filling would enhance the holes' habitat values (TBEP 2005). The TBEP subsequently received grant funding to study an additional 11 holes in 2017. That study is similar in scope to the TBEP (2005) study, and that report is presently in preparation. Figure 8-1 shows the location of the holes studied in the 2005 survey, as well as the holes in the 2017 study (TBEP 2005).

McKay Bay Dredged Hole, one of the holes recommended for restoration in the 2005 report, was restored in 2014-2015 using grant funding obtained from the Southwest Florida Water Management District and the TBEP. Information on each of the remaining three holes recommended for restoration is provided below for reference. Restoration of the 11 
additional holes may be considered in the future based on the recommendations in the 2017 report when it becomes available.

Figure 8-1. Dredged hole management recommendations from TBEP (2005) Technical Publication 04-05 (2006 shown in blue), as well as the locations of the holes in the 2017 TBEP study (shown in orange; report in preparation).

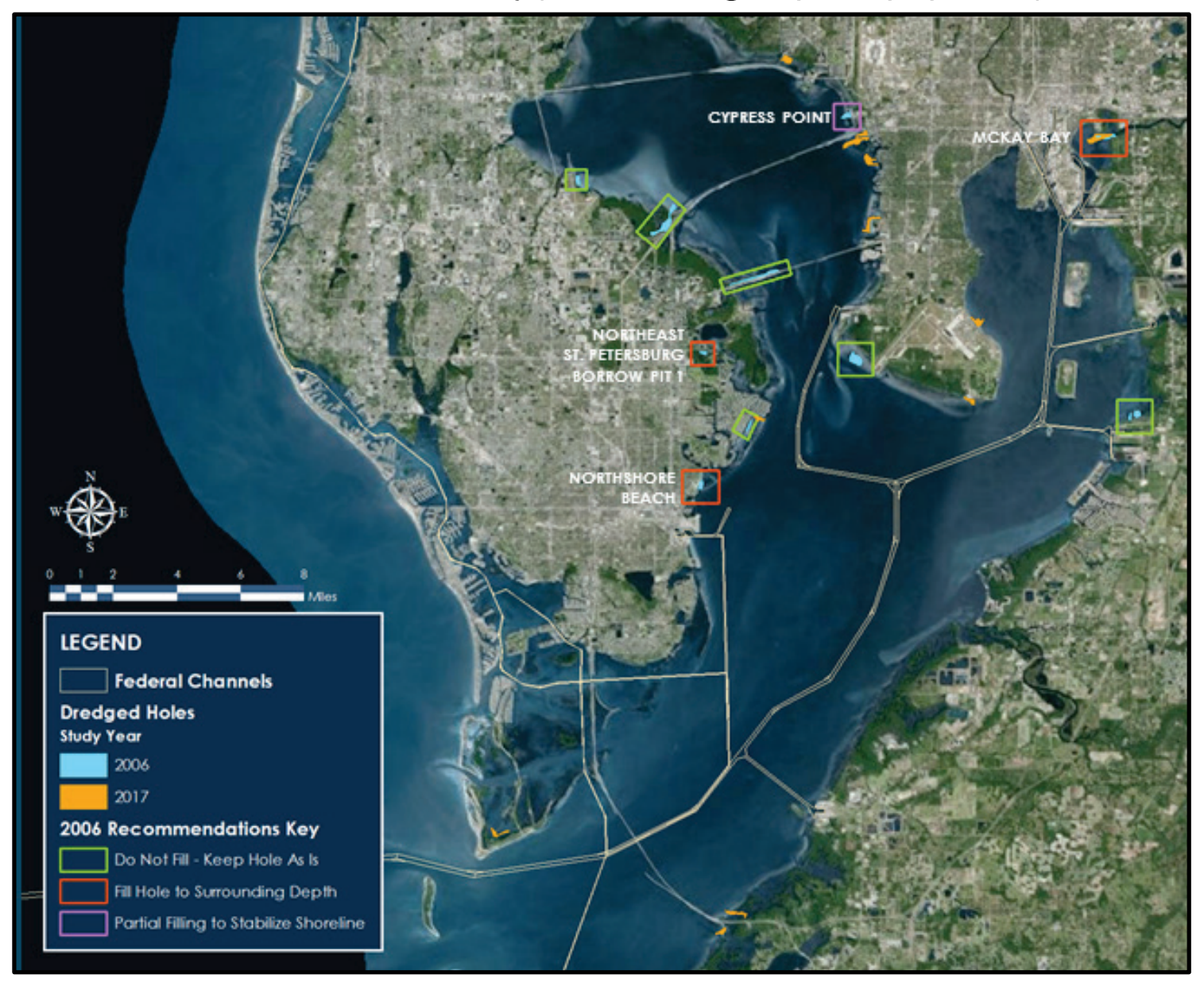

\subsubsection{Cypress Point dredged hole}

Management recommendation was to "Partially fill hole to stabilize the shoreline and reduce erosion. Fill to various depths, including to the photic zone" (TBEP 2005).

The Cypress Point hole was dredged for fill material to facilitate upland development north of the Howard Frankland Bridge, including the Westshore Mall. The surrounding area is beach and sand flat with patchy seagrass/algae coverage. The hole is under the ownership of the Tampa Port Authority. TBEP (2005) noted that in 2005 the feasibility of USACE 
material delivery was low. No management activity is known to have occurred within this dredged hole.

- Approximate size: 39.5 acres

- Maximum depth: $-11.9 \mathrm{ft}$

- Surrounding area depth: $-2.5 \mathrm{ft}$

- Fill volume to reach depth of: $-3 \mathrm{ft}: 449,851 \mathrm{cy} ;-4 \mathrm{ft}: 358,658 \mathrm{cy} ;-5 \mathrm{ft}$ : 279,336 cy

- Habitat type: polyhaline mud

\subsubsection{Northeast St. Petersburg Borrow Pit 1}

Management recommendation was to "Shallow up hole to between -10 feet $(f t)$ and $+3 f t$ to address hypoxia. Develop intertidal planting shelves with the potential for saltmarsh, mangroves, and intertidal oyster growth" (TBEP 2005).

The Northeast St. Petersburg Borrow Pit 1 is located adjacent to the Pinellas County Aquatic Preserve in northeast St. Petersburg. The hole was dredged to provide fill for the Mangrove Bay Golf Course, a large mobile home park, and adjacent residential areas. Several small-scale restoration projects have been completed in the vicinity, including using excavated fill from a marsh restoration project to partially fill other borrow pits and to re-contour a portion of the golf course shoreline. The hole is under the ownership of the City of St. Petersburg. TBEP (2005) noted that in 2005 the feasibility of USACE material delivery was high. No management activity is known to have occurred within this dredged hole.

- Approximate size: 10.9 acres

- Maximum depth: $24.4 \mathrm{ft}$

- Surrounding area depth: $3.0 \mathrm{ft}$

- Fill volume to reach depth of: $-3 \mathrm{ft}: 201,249 \mathrm{cy} ;-4 \mathrm{ft}: 187,563 \mathrm{cy} ;-5 \mathrm{ft}$ : 173,940 cy

- Habitat type: polyhaline mud

\subsubsection{Northshore Beach dredged hole}

Management recommendation was to "Fill hole to surrounding depth to encourage expansion of seagrasses” (TBEP 2005). 
The Northshore Beach hole was dredged to create the recreational beach and portions of North Shore Park in St. Petersburg. The large offshore dredged hole could potentially create a public safety hazard as people wade offshore and into rapidly increasing water depth. The area is surrounded by a deep sand flat with patchy seagrass and algae. The hole is under the ownership of the City of St. Petersburg and the State of Florida. TBEP (2005) noted that in 2005, the feasibility of USACE material delivery was high. No management activity is known to have occurred within this dredged hole.

- Approximate size: 41 acres

- Maximum depth: $17.7 \mathrm{ft}$

- Surrounding area depth: $1.5 \mathrm{ft}$

- Fill volume to reach depth of: $-3 \mathrm{ft}: 440,795 \mathrm{cy} ;-4 \mathrm{ft}: 384,119 \mathrm{cy} ;-5 \mathrm{ft}$ : $331,078 \mathrm{cy}$

- Habitat type: polyhaline mud

\subsection{Sediment requirements}

Ideally, dredged holes would be filled with rock or coarse sand and capped with material that is similar to the surrounding substrate. As previously mentioned, seagrasses are found in a variety of substrates throughout Tampa Bay. Silty material can billow out of a dredged hole if covered with heavier material, causing localized turbidity if not contained.

The substrates in upper Tampa Bay are siltier than those in the center and in the mouth of the Bay. Restoration completed using material dredged near the restoration site is generally preferable both from substrate suitability and cost standpoints. Exceptionally silty materials would require the use of flocculants to reduce turbidity and to minimize impacts to adjacent seagrass communities. Resource agencies have expressed some concern over the use of flocculants in Tampa Bay, which may limit the quantity of dredged materials available for use.

\subsection{Construction methods}

Cutter suction or mechanical (clamshell/excavator) dredges are most suited for dredged hole restoration, although a small hopper dredge with pump-out capabilities would also be able to accomplish the work. A cutter suction dredge completing the work would most likely be small (10 in. to 16 in.), and the material could be piped directly into the bottom of the 
dredged hole. A clamshell dredge would dredge the material and place it into scow barges. A hydraulic unloader would slurry the material from the scow barges and transport it through pipelines to the hole. Some examples of seagrass restoration constructed through filling dredged holes are Harbor Isles in St. Petersburg and the seagrass mitigation constructed in Biscayne Bay for Miami Harbor.

Most dredged holes are located in areas where the surrounding water depths are shallow enough to promote seagrasses. High turbidity can impact seagrass growth; therefore, minimizing and controlling turbidity is important during the placement of material. In general, it is best to start at the bottom of the hole and fill it up rather than discharging material from a pipe located at the top of the hole.

Diffusers can be installed at the end of the pipe to slow the velocity of the material and spread it evenly into the hole. Without the use of a diffuser system, disposal methods would greatly increase the surrounding water column turbidity, temporarily decreasing water quality. However, using a pump-out and diffuser system is less efficient than straight bottom dumping and increases costs. Flocculants, which are substances that are used to promote the clumping of silty material, can be added to the fill material to reduce turbidity; however, they have been variably successful during past efforts, and concerns have been raised regarding ancillary impacts to other natural resources. Other measures used to control turbidity are turbidity barriers, silt screens, or a ring-berm confinement feature (constructed from hay bales or other biodegradable materials). The most appropriate turbidity control method should be chosen based on site conditions.

Although slurrying the material and placing it directly into the dredged hole via pipeline is the most common method of restoring dredged holes, some projects have used conveyor systems to place the material in a way that decreases turbidity by using less water. Scow barges must navigate close to the dredge hole, and then a barge-mounted hydraulic dredge unloads the dredge material and places it into a hopper system. The hopper system feeds the material onto conveyors that are mounted on barges. The conveyors transport the material to the dredge hole, where it is offloaded. This approach helps to minimize turbidity, since the material is only saturated rather than slurried with high volumes of water. Similar 
operations have been performed along the intracoastal waterway along the East Coast of Florida ${ }^{1}$.

Water depths surrounding most of the dredged holes are fairly shallow. Shallow depths may not allow for dredge barges to efficiently access the restoration site for disposal. Barges may need to be light-loaded, or filled to less than their maximum capacity, to decrease their required draft depth and access the shallower areas of the Bay. Alternatively, they would need to utilize additional pipe to access the areas and expend more energy to force the material longer distances through the pipeline. Both of these options would result in higher disposal costs. Although restoring dredged holes provides suitable habitat for the establishment of seagrasses, accessing these sites could have a potential for impacting adjacent seagrasses due to the transiting of dredge equipment and the installation of the dredge pipelines in the proximity of existing seagrasses.

\subsection{Restoration costs}

The construction components associated with filling a dredged hole with material from a navigation channel that incur costs to the project are listed below, as well as their associated cost per unit of measure. Based on the specifics of a proposed project, the costs can be combined to calculate the anticipated cost of placing material from any dredged location on the beach.

\subsubsection{Dredging}

As mentioned in Section 6.4.1, dredging costs can vary based on the volume placed, the distance the material is transported, the type of material dredged, and the location of dredging. USACE recently advertised a maintenance dredging project and received an average bid of $\$ 18 /$ cy for placement of dredge material in DMMA 3-D. This price included all costs associated with dredging, transportation, and placement of the material up to 10 miles from the dredge site. Disposal of material in DMMA 3-D typically is not a separable cost from the dredging work. However, for discussion purposes, this price could be assumed to be $\$ 2-\$ 3 /$ cy of the total $\$ 18 /$ cy unit price. Similar equipment would likely be utilized for both filling a dredged hole and for placing material in DMMA 3-D; therefore, these would have similar costs and $\$ 18 / \mathrm{cy}$ would be a reasonable estimate

\footnotetext{
1 Steve Conger, U.S. Army Corps of Engineers, Jacksonville District (SAJ), personal communication, 23 June 2016.
} 
for transport of material up to 10 miles (not accounting for any additional project requirements).

- COST: $\$ 18 /$ cy of material (up to 10 miles)

\subsubsection{Material transport}

Transporting the material to an alternate site from the DMMA, such as to a dredged hole, is estimated to cost approximately an additional $\$ 1 /$ cy/additional mile.

- COST: $\$ 1 /$ cy/mile (over 10 miles)

\subsubsection{Turbidity containment}

Placing hay or pine straw bales in a pyramid of three is estimated to cost $\$ 8 /$ linear (lin) $\mathrm{ft}$. The current prices of pine straw are slightly cheaper than hay, but for the purposes of this discussion they are considered to be the same. Prices of hay can fluctuate each year depending on market conditions and the availability of this product. Type 2 turbidity curtains are estimated to cost $\$ 120 /$ lin $\mathrm{ft}$, based upon recent pricing information. These curtains are connected and anchored at the top and bottom, which is costlier than more basic Type 1 curtains $(\$ 50 /$ lin $\mathrm{ft}$ ). While the additional cost of turbidity containment is provided as a cost per linear foot of dredged hole perimeter, it is estimated that these combined features implemented to fill a dredge hole large enough to hold approximately 200,000 cy of material could add approximately $\$ 14 /$ cy above the cost for placing in DMMA 3-D.

- COST: $\$ 128 /$ lin $\mathrm{ft}$ of dredged hole perimeter

\subsubsection{Other considerations}

There would likely be reduced production associated with accessing shallow sites or filling holes requiring a small volume of material (e.g., where two disposal locations are required). Reduced production results in additional costs to the project. A small hydraulic unloader could reasonably pump material in shallow water up to 2,000 lin $\mathrm{ft}$ within the costs presented above. Pumping beyond this distance or filling multiple dredge holes in one contract could result in additional costs that cannot be accurately estimated without more detailed scoping information. 


\section{Island Creation/Stabilization}

\subsection{Background and opportunities}

Tampa Bay is home to a number of important nesting shorebird and seabird colonies. They currently inhabit the actively managed DMMAs, as well as several other islands located in the Bay. There are two active DMMAs located in the Bay: one primarily used by Port Tampa Bay (DMMA 2-D) and the other by USACE (DMMA 3-D). These islands support large colonies of nesting shorebirds each summer because of their general lack of vegetation through ongoing placement of dredged materials and due to the lack of predators (both human and mammalian) at the site.

The Alafia Bank Sanctuary, comprised of Bird Island and Sunken Island, was originally created in the 1920 s during the construction of a navigation channel that connects the Alafia River to the Tampa Harbor main navigation channel. These islands are managed by Audubon Florida as a sanctuary for up to 18,000 nesting pairs of 16 to 20 species of birds. They are one of the largest colonies in Florida and one of the most diverse colonies in the continental United States. The Florida Fish and Wildlife Conservation Commission (FFWCC) lists the Alafia Bank Sanctuary as the most important colony in the state due to its size, longevity of nesting activity, and species diversity. Audubon Florida would like to expand the Alafia Banks Sanctuary and has offered to assist in any permitting effort that may be required to accomplish an expansion. Figure 9-1 shows potential expansion opportunities at Alafia Banks Sanctuary. Audubon Florida also offered to provide labor required for planting and monitoring the expanded site, thus making this an excellent opportunity to beneficially use material in this area.

Other islands in the Bay also provide important bird habitat but vary in the protection they provide to the birds due to their frequent use by recreational boaters. The USFWS has noted the need for additional roosting sites throughout Tampa Bay for birds to rest in locations protected from human disturbance, especially in Old Tampa Bay. Red knots are often observed roosting along the three causeways that span Old Tampa Bay, and they are frequently flushed from their perches by recreational bikers, fishermen, and joggers. Roosting is important for many migrant species, including the federally protected red knot, to build and to maintain the energy reserves required for their long migrations. If 
material were available in the western portion of Tampa Bay, this may be a good opportunity to partner with USFWS to create roosting sites in the Bay that provide protection from human disturbance.

Figure 9-1. Potential expansion opportunities at Alafia Banks Sanctuary.

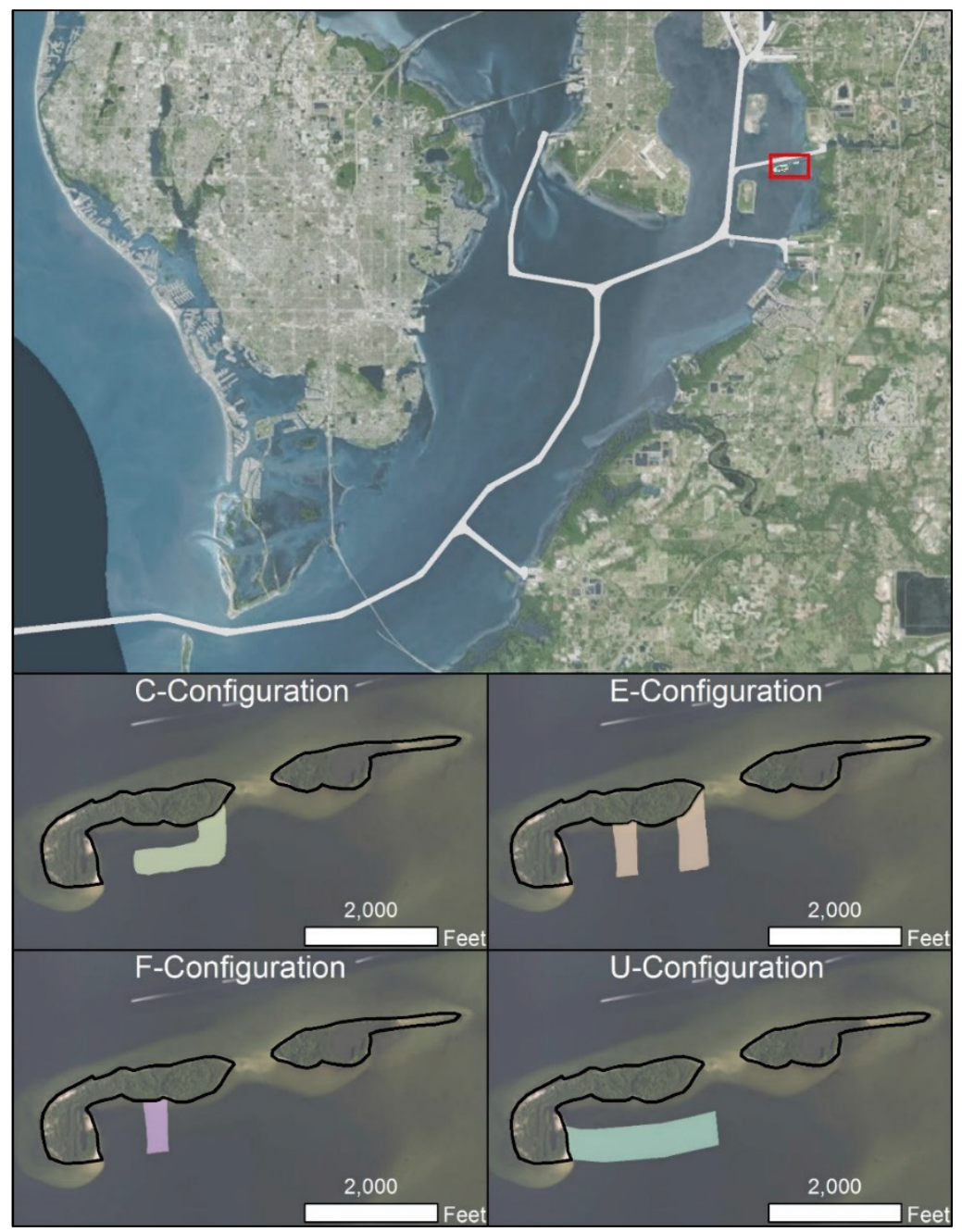

\subsection{Sediment requirements}

Material obtained from expansion projects to widen or deepen channels or berths would be ideal for creating island habitats; however, other materials may suffice with the use of appropriate containment structures (e.g., hay bales or geotubes). Construction material, as opposed to maintenance material, generally contains some limestone rock and/or clay in this region, which provides a firmer base for the sediment. The base material could be covered with sandy or silty sand material with the implementation of the appropriate turbidity containment measures. This 
would allow for the project to be completed over a number of dredging cycles if the required volumes were not available in one project alone. This method was used in the USACE Mobile District where it deployed barriers to contain maintenance material placed over a number of years until the required depths were reached to create marsh habitat.

\subsection{Construction methods}

The perimeter of the expansion area would be delineated through the placement of riprap or geotubes. Material obtained from new construction (i.e., the widening or deepening of a channel or berth) is likely to be dredged with mechanical or hydraulic dredges, and the material would be placed at the island creation site using a method similar to placing at DMMA 3-D or on the Egmont Key beach.

Maintenance material may be placed at the site using a combination of high density polyethylene pipe, flexible floating pipe, or rigid steel pipe, based on the contractor's available equipment. Conveyors could be used to transport the material from barges to the placement site; however, this has not previously been done in Tampa Bay.

\subsection{Restoration costs}

The construction components associated with island creation with material from a navigation channel that incur costs to the project are listed below, as well as their associated cost per unit of measure. Based on the specifics of a proposed project, the costs can be combined to calculate the anticipated cost of placing material from any dredged location on the beach.

\subsubsection{Dredging}

As stated previously, dredging costs can vary based on the volume placed, the distance the material is transported, the type of material dredged, and the location of the dredging. USACE recently advertised a maintenance dredging project and received an average bid of $\$ 18 /$ cy for placement of dredge material in DMMA 3-D. This price included all dredging and the transportation of the material up to 10 miles. It is estimated that $\$ 2-\$ 3 / c y$ of this estimate could be attributed to the disposal operations specific to the upland site and would not be applicable to island creation. Due to the similarity between the equipment required to place at an island creation site, it is anticipated that the same dredging estimate could be used for the 
dredging and placement associated with island creation when the dredge site is located within 10 miles of the placement site.

- Cost: $\$ 18 /$ cy of material

\subsubsection{Material transport}

Transporting the material to an alternate site from the DMMA, such as to the island creation site, is estimated to cost approximately an additional $\$ 1 /$ cy/additional mile.

- Cost: $\$ 1 / \mathrm{cy} / \mathrm{mile}$ (over 10 miles)

\subsubsection{Island stabilization}

Costs for island stabilization and secondary turbidity containment associated with island creation would be best accomplished through the placement of geotubes or riprap. These techniques provide protection for a longer timeframe than hay or pine straw bales. The geotubes could be constructed from burlap to allow them to break down over time.

- Cost: $\$ 21 /$ cy of geotube or riprap perimeter placement

\subsubsection{Other considerations}

Reduced production associated with accessing shallow sites, or for options requiring a small volume of material (possibly requiring two disposal locations), could increase the project's cost. A small hydraulic unloader could reasonably pump material up to 2,000 lin $\mathrm{ft}$ within the costs presented, but mechanical dredges may have increased costs based on their available equipment. In addition, the cost per cubic yard goes down with increased volumes, which makes it more cost effective to build a larger island than to build smaller islands. 


\section{Longshore Bars}

\subsection{Background and opportunities}

Longshore bars are sandbars situated parallel to the shoreline and hypothesized to play a role in long-term seagrass persistence and/or recovery. In many parts of Tampa Bay, longshore bars and seagrasses are found concurrently. Figure 10-1 depicts a cross section perpendicular to a longshore bar showing seagrass zonation. Seagrasses growing on the seaward side of the bars may accumulate sediments, potentially forming or maintaining bar structures. The bars, in turn, may dampen wave energy, creating a more favorable and less energy-intensive environment for seagrasses (Lewis 2005). Longshore bars may also provide storm damage reduction to upland infrastructure. While longshore sand bars are prevalent in Tampa Bay, their extent and distribution has declined since the mid-1900s (Lewis et al. 1985; Lewis and Estevez 1988).

Figure 10-1. Graphic depicting longshore bars and seagrass zonation in Tampa Bay (Lewis 2005).

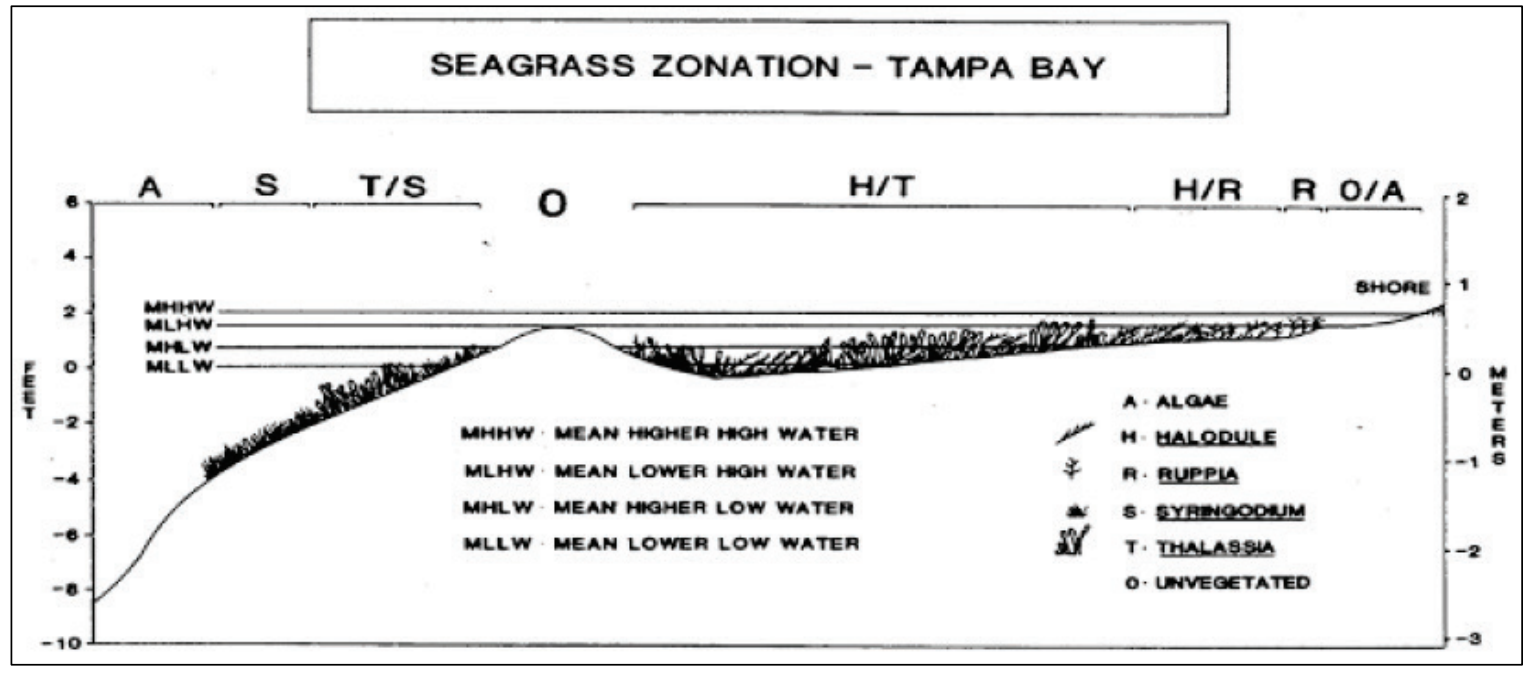

Photointerpretation and mapping of longshore bars in seagrass meadows in Tampa Bay using historical and current vertical aerial photographs identified that the visible length of longshore bars from circa 1940 to 2004 declined by 43.2\%. Figure 10-2 shows the loss of longshore bar from 1957 with the same location in 1990 in Tampa Bay. The total number of bar features initially declined by $26 \%$ from 1940 through 1980 , but an increase was observed between 1980 and 2004. The more recently developed longshore bar features are generally smaller in length than historical bars, 
which may be due to their more recent establishment. This phenomenon is consistent with the hypothesis that seagrasses and longshore bars are somewhat interdependent, considering the recent recovery of seagrasses in the Bay since the mid-1990s (Lewis 2005). The extent of longshore bars in Tampa Bay observed from aerial photography in 1940, 1950, 1980, and 2004 is shown in Figure 10-3 (Lewis 2005).

Figure 10-2. Comparison of historical longshore bar location from 1957 and the same location in 1990 in Tampa Bay (Lewis 2005). Loss of longshore bars in Tampa Bay may have led to a loss of seagrass in front of, and behind, the bars.

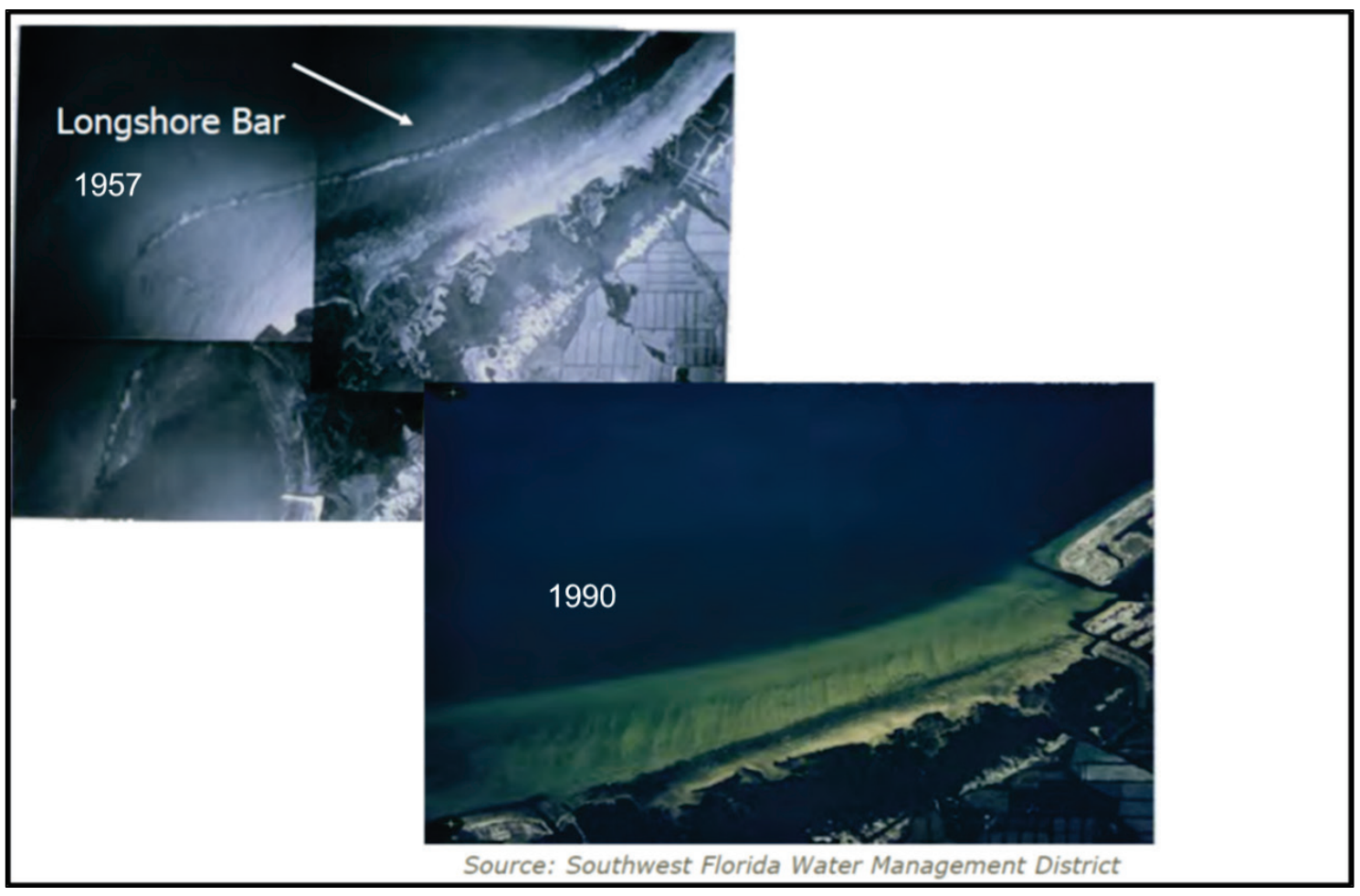


Figure 10-3. Comparison of historical longshore bar location from 1957 and the same location in 1990 in Tampa Bay (Lewis 2005). Loss of longshore bars in Tampa Bay may have led to a loss of seagrass in front of, and behind, the bars.

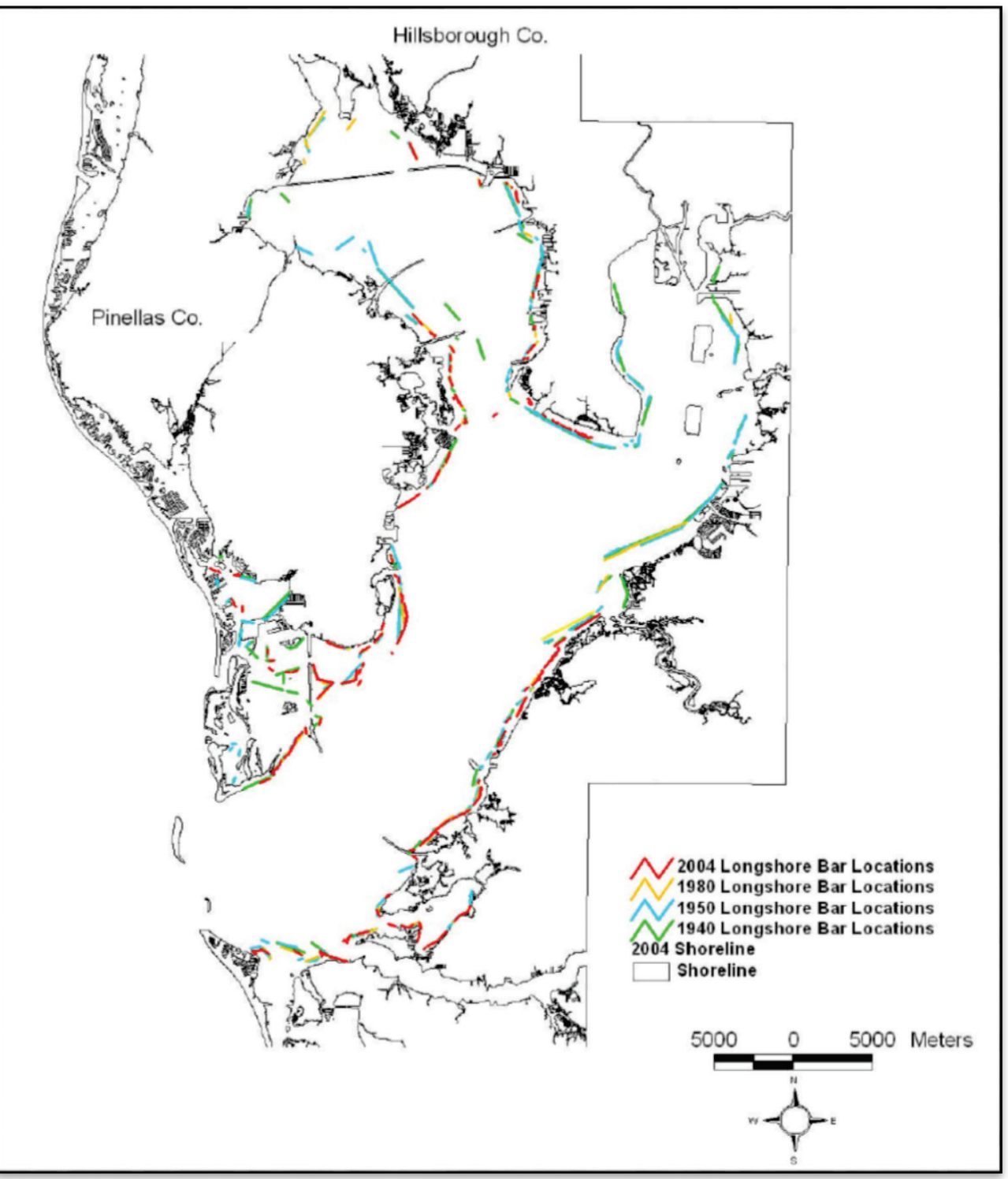

\subsubsection{Tampa Bay Estuary Program (TBEP) pilot project}

As part of its goal to restore seagrass coverage to 1950s extents, the TBEP acquired grant funding to study the effects of restoring longshore bars on the adjacent seagrass community (Cross 2013). The project was conducted in partnership with the Port Tampa Bay, with engineering designs by Malcom Pirnie and monitoring conducted by Scheda Ecological Associates, Inc. The engineering objectives of the study were to construct a $950 \mathrm{ft}$ long bar system utilizing four, $200 \mathrm{ft}$ long sections with a $50 \mathrm{ft}$ 
separation between each section. The bar was designed to function as one longshore bar; however, the separations allowed water movement between the sections and investigation into the long-term viability of each section. The artificial bars were designed to be approximately $2 \mathrm{ft}$ below the surface of the water at mean high tide and to be exposed at low tide. The sections ranged in width from 12 to $23 \mathrm{ft}$ wide. The resource agencies involved with the permitting of the pilot project preferred that the construction materials and the design focus on creating fairly permanent features to maximize the value of the project. Taking this concern into consideration, the study used the following four experimental bar designs, shown in Figure 10-4.

\subsubsection{Design 1. Medium-sized riprap with a minimum diameter of 12 in.}

- Design 2. Two parallel rows of Jersey highway barriers, with oyster shell placed between the rows

- Design 3. Sand covered with geo-fabric and topped with small riprap material

- Design 4. Reef balls measuring $4 \mathrm{ft}$ wide by $2.9 \mathrm{ft}$ tall, placed in three staggered, offset rows

While the Tampa Bay Longshore Bar Seagrass Recovery Project outlined beneficially using dredged material as an objective to developing engineering critera for the artificial bars, the desire to create permanent features factored into the creation of Design 3. Design 3 uses sediment as the base, but covers the sediment with a layer of geo-fabric and riprap. Port Tampa Bay obtained environmental permits from the Florida Department of Environmental Protection (FDEP; Permit No. 290268608-004), USACE (Permit No. SAJ-2007-5671-LP-MLS), and the Tampa Port Authority (Permit No. 07-155). In addition, the team received authorization from the United States Coast Guard (USCG)(PATON Permit No. 08-003) and (FFWCC) to install six danger, submerged structure warning signs around the perimeter of the project, per FFWCC specifications. 
Figure 10-4. Photograph of the project area showing each of the four experimental bar designs. From the background to the foreground: 1. Riprap; 2 . Jersey highway barriers; 3. Sand covered with geo-fabric and riprap; and 4. Reef balls. Photograph was taken from the east, facing toward the west.

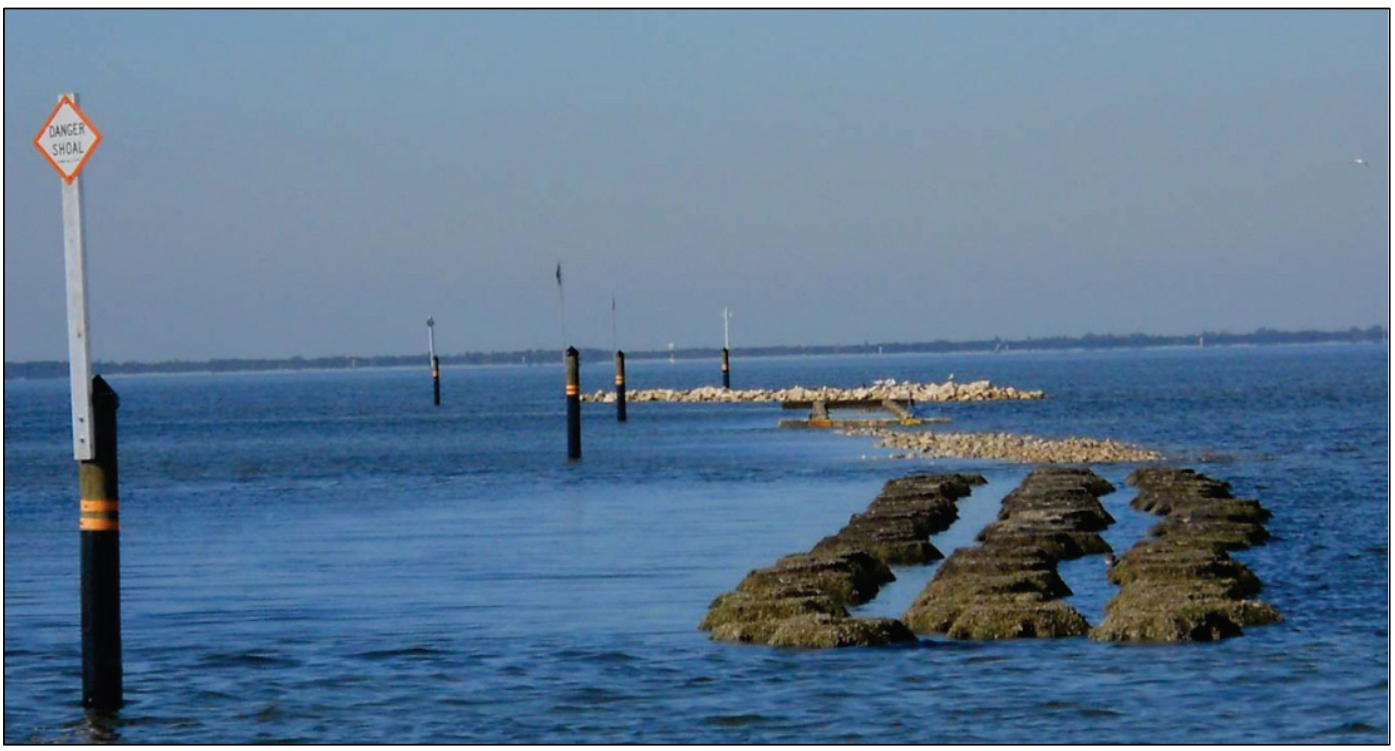

TBEP and Scheda Ecological Associates, Inc., conducted monitoring for a 5-year period from 2011 through 2016. A summary of the study results included the following:

1. Observation of an $80 \%$ increase in seagrass cover over the entire 5 -year monitoring period.

2. Documentation of some scouring at the terminal ends, especially associated with the Jersey barriers. Much less scouring was observed with the other three treatments.

3. Noted some minor accretion, as well as an increase in organic composition, landward of the structures.

4. All four structures provided essential fish habitat (EFH); however, the reef balls exhibited the highest value habitat in the form of encrusting organisms and fish utilization.

5. Seagrass diversity increased from only shoal grass to include patches of turtle and manatee grass.

6. Seagrass bed densities increased substantially during the monitoring period $^{1}$.

\footnotetext{
1 Tom Ries, Scheda Ecological Associates, Tampa, Florida, personal communication, 22 February 2017.
} 


\subsubsection{Potential future projects}

USACE built upon the findings of the Lewis (2005) report and the results of the Tampa Bay Longshore Bar Seagrass Recovery Project to identify possible locations for additional longshore bar restoration opportunities. USACE identified locations throughout Tampa Bay where longshore bars historically occurred but where they were no longer present (Figure 10-5). The Tampa Bay Longshore Bar Seagrass Recovery Project found that longshore bar features positively affect seagrass communities and that sand placement provides the most natural solution while also presenting the least potential hazard to mariners. In addition, incorporating any available rock into the bar feature would enhance EFH and potentially provide roosting opportunities for avian species if exposed during low tide ${ }^{1}$.

Figure 10-5. Locations of historic and current (2004) longshore bars in Tampa Bay. The green shows the current extents while the pink indicates the historic extents. Areas in Old Tampa Bay (the northwest portion of the Bay) and Hillsborough Bay (the northeast portion of the Bay) have experienced the most significant longshore bar losses and would be the most appropriate areas in which to focus restoration opportunities.

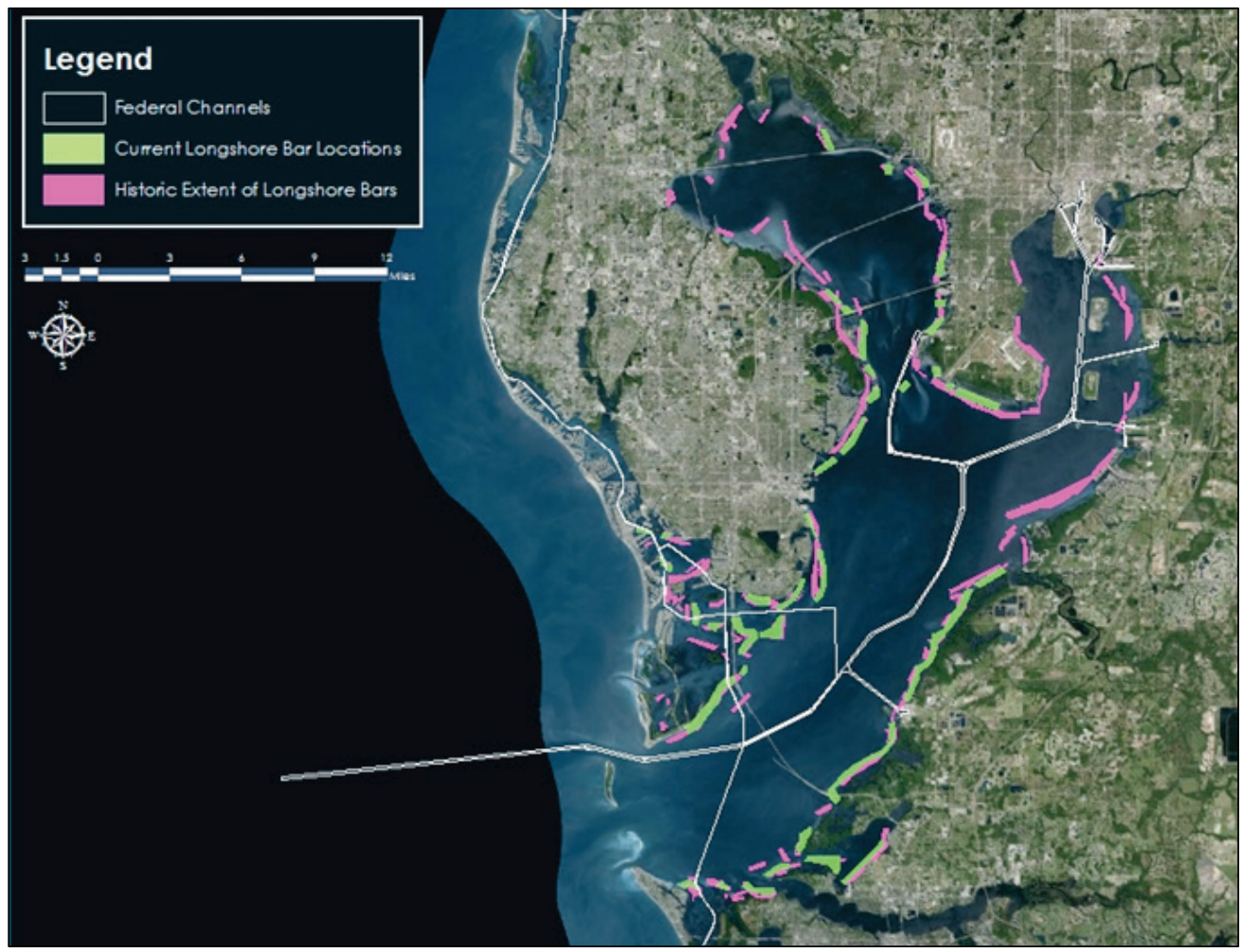

1 Tom Ries, Scheda Ecological Associates, Tampa, Florida, personal communication, 22 February 2017. 


\subsection{Sediment requirements}

Longshore bars would ideally be constructed with sandy sediments or rock; however, silty sand may be an option if properly contained using hay bales, burlap containment tubes, or riprap. Turbidity curtains may also be required if the material were primarily silty sand. Silt is not recommended due to the potential for it to readily migrate from the placement site.

\subsection{Construction methods}

Although the size of the longshore bar design could vary based on the location, the proposed features would be between 20 and $25 \mathrm{ft}$ wide and could range from $100 \mathrm{ft}$ to several thousand feet long. Burlap tubes could be filled and used in place of geotubes or hay bales to stabilize material. This would negate the requirement to use turbidity curtains or hay/pine bales to control turbidity, and the burlap would biodegrade over time. Due to their high cost, the use of tubes should be limited to the seaward side of the longshore bar feature. The landward side would be protected from wave action and should be naturally stabilized.

Hay bales are another option that would also stabilize the material and allow it to settle into a more permanent feature. Monitoring of the Tampa Bay Longshore Bar Seagrass Recover Project found the incorporation of rock features into the longshore bar design provided fish habitat; however, they posed a potential navigational threat to mariners compared to a feature that was composed solely of sediment.

As these are soft features in the seafloor landscape, it should be expected that the sediment may migrate either landward or seaward. Landward movement of the sediment could help adjacent seagrass habitat mitigate for sea level rise by raising the substrate level gradually, but care must be taken to ensure that existing seagrass communities are not negatively impacted.

\subsection{Restoration costs}

The cost of constructing longshore bar features is higher than the previous alternatives primarily due to the small volumes of sediment required to create each feature and the measures required to stabilize the features and to minimize turbidity. The construction components associated with material from a navigation channel that incur costs to the project are listed below, as well as their associated cost per unit of measure. Based on the 
specifics of a proposed project, the costs can be combined to calculate the anticipated cost of placing material from any dredged location on the beach.

\subsubsection{Dredging}

Dredging costs for longshore bars would be comparable to costs outlined for other placement methodologies at approximately $\$ 15 /$ cy, which includes transportation up to 10 miles from the dredge site.

- Cost: $\$ 18 /$ cy of material

\subsubsection{Material transport}

As discussed for other placement options, transporting material over 10 miles would cost an additional $\$ 1 /$ cy/additional mile.

- Cost: $\$ 1 / \mathrm{cy} / \mathrm{mile}$ (over 10 miles)

\subsubsection{Turbidity containment}

Costs for turbidity containment associated with longshore bar restoration would be similar to those previously described in Section 8.4.3 for Dredged Hole filling. Placing hay or pine straw bales in a pyramid of three is estimated to cost $\$ 8 /$ lin $\mathrm{ft}$. Depending on resource agency comments, additional turbidity control measures may not be necessary or required. In addition, it may be sufficient to install hay bales only on the seaward side of the bar feature rather than on both sides. This would substantially reduce costs.

- Hay/Pine bale: $\$ 8 /$ lin $\mathrm{ft}$

- Turbidity curtains (Type 2): $\$ 120 /$ lin $\mathrm{ft}$

\subsubsection{Other considerations}

Longshore bars were the most expensive RSM opportunity due to the relatively small volume of material placed and the intensive turbidity control measures required to place it. In addition to burlap or geotubes, costs for several other materials used to restore longshore bars and to stabilize shorelines are provided below for reference.

- Geotubes (textile or burlap): $\$ 590 /$ lin $\mathrm{ft}$

- Riprap: \$500/lin ft

- Jersey barriers: $\$ 920$ each

- Reef balls: $\$ 75$ - $\$ 400$ each 


\section{Thin Layer Placement}

While thin layer placement was ranked least among the options and strategies discussed at the two stakeholder meetings, its use is becoming increasingly popular in other parts of the United States for marsh restoration. Therefore, information on the strategy and its potential use in Tampa Bay is included here for future reference. Seagrass habitat has expanded extensively in Tampa Bay since 1982, reaching coverage comparable to that observed in the 1950 s. The recovery is primarily attributed to bay-wide water quality improvements. However, sea level rise threatens seagrasses and emergent tidal wetlands (PBS\&J 2010). Further study on the status of marsh habitats in Tampa Bay is necessary to identify if and where restoration would be beneficial using a method such as thin layer placement.

\subsection{Background and opportunities}

Thin layer placement is a technique employed to artificially supply sediment to marshes by using high pressure to spray a sediment slurry over the marsh surface (Figure 11-1). The technique is a modification of existing hydraulic dredging methods in which sediments are hydraulically dredged, liquefied, and pumped through a high-pressure tube. The slurry is typically sprayed to a thickness of 4 to 8 in., which allows the marsh vegetation to penetrate the layer and grow comparably to undisturbed reference marshes. Thin layer placement is one method of increasing the stability of the coastline by combating the deterioration of coastal wetlands due to sediment depletion, subsidence, and sea level rise. 
Figure 11-1. Thin layer placement during the New Jersey Avalon Pilot Project (photo by Chasten and Goldberg 2016).

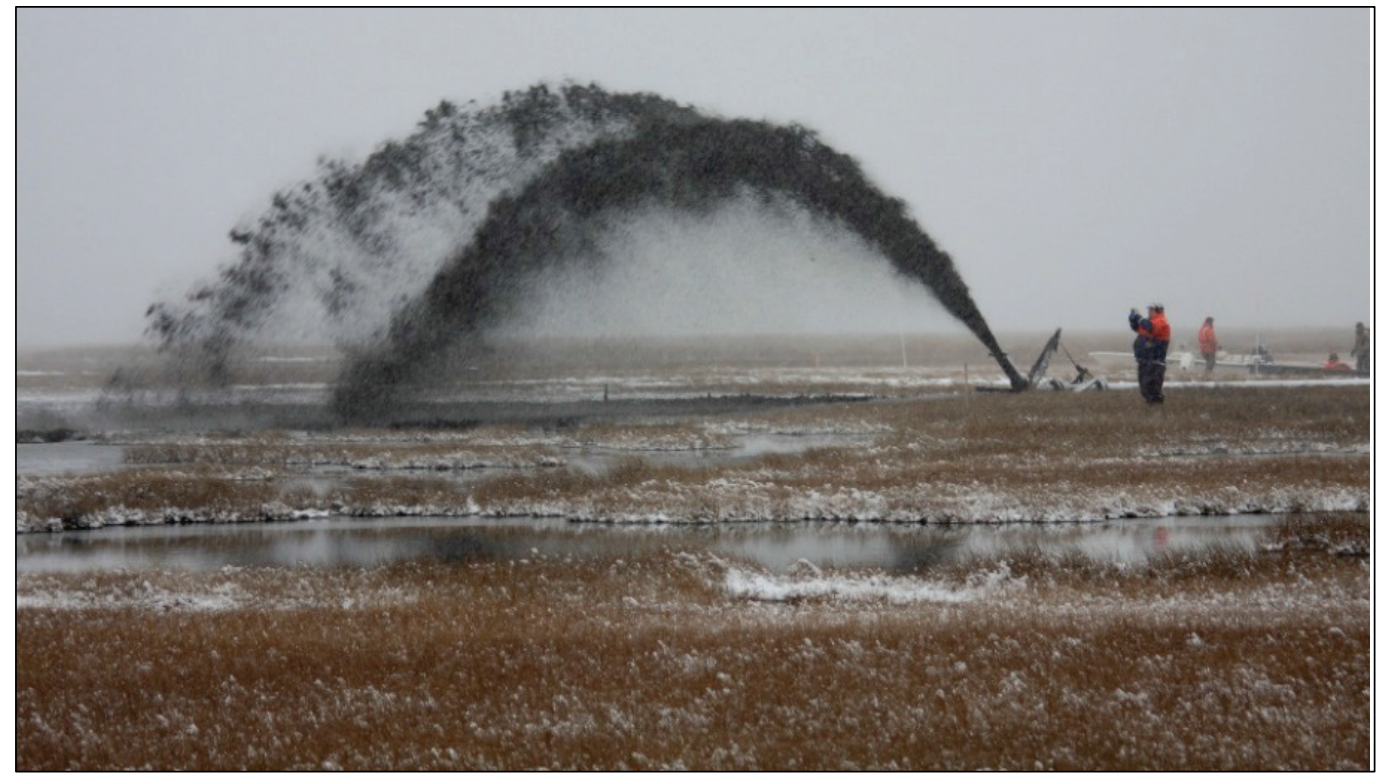

Traditional methods of spray disposal, including bucket dredging and low-pressure spray disposal, have limited the physical range of sediment placement and have tended to deposit the materials in uneven layers of poorly mixed sediment. Thin layer placement is capable of placing material at ranges 2-3 times greater than traditional methods, and it produces a well-mixed slurry in uniform layers. Spray disposal is also capable of handling a variety of sediment types ranging from sands to heavy clays and organic sediments.

Although most ecosystem projects using thin layer placement as a restoration strategy involve the placement of material over existing marshes, the USACE Mobile District has used a third method of depositing material as a thin layer, open-water placement. This method was used at the historic open-water disposal areas in Mobile Bay, Alabama. Material was placed in areas ranging from approximately $-6 \mathrm{ft}$ to $-10 \mathrm{ft}$ mean lower low water, with placement not exceeding 12 in. thickness.

One major concern of this alternative was not knowing how the sediment would behave once placed in the open-water areas. To understand how the placed sediments dispersed and transported throughout Mobile Bay and whether there could be impacts on existing ecological resources, the U.S. Army Engineer Research and Development Center performed a study (data collection, laboratory analysis, numerical modeling) to assess the dispersion of the material placed in Mobile Bay (Parson et al. 2015). The 
study indicated that thin layer sediment placement in the bay would have negligible impact on navigation channel infilling, total suspended sediments, and Mobile Bay bottom morphology. There are no natural resources located in this region of Mobile Bay.

Thin layer placement does have some significant limits. Site access is a primary consideration because the receiving area needs to be adjacent to a body of water deep enough to provide access for the dredging equipment. The placement is also limited by the range of the spray equipment. Despite having a range $2-3$ times greater than traditional methods, the highpressure spray is limited to a range of less than $330 \mathrm{ft}$ from the equipment. This limits the use of this technique to marshes that border relatively deep bodies of water. In the case of Tampa Bay, this should not be a major concern because there is access to most of the potential marsh sites through the bay. One concern with using the high-pressure spray is the turbidity that it produces in the water. In areas with sensitive species of seagrass, the potential impacts of the turbidity could be large. Awareness of the location of seagrasses in the area is critical when considering using thin layer placement.

It is necessary to measure the health of a marsh and its risk of degradation due to subsidence and/or sea level rise prior to identifying appropriate sites for restoration. Cahoon et al. (1995) notes the importance of considering vertical accretion, shallow subsidence, compaction, shrink/swell from water storage, and plant production/decomposition when evaluating potential surface elevation change at a project site, and the subsequent risk of marsh degradation. In some instances, an influx of sediment to a subsiding marsh habitat can enhance plant growth (Pezeshiki et al. 1992). Tidal wetlands in Tampa Bay are currently dominated by mangroves; however, historical imagery indicates that tidal marshes with a mangrove fringe were dominant features throughout the bay in the late 1800 s. Raabe et al. (2012) found that the ratio of marsh-tomangroves in Tampa Bay changed from 86:14 to 25:75 over 125 years. This conversion could be attributed to a combination of climate change, river discharges, and urbanization impacts (Raabe and Gauron 2007).

Sea level rise in Tampa Bay from 1870 to 1999 was approximately 12 in. This may have resulted in the loss of intertidal habitat as the shoreline boundary migrated inland but is now blocked by the presence of upland development. Tampa Bay is located at the northern end of extensive red or 
white mangrove habitat as winter freeze events typically prevent their spread north of this region. Warmer temperatures result in fewer freezes, which are potentially a contributing factor to the spread of mangroves in Tampa Bay. Armitage et al. (2015) document similar observations on the Texas coastline. Salinity also affects the distribution of marsh and mangrove habitats, and the conversion from marshes to mangroves was less prevalent in areas with higher freshwater discharges (Raabe et al. 2012). The records for the Hillsborough and Alafia Rivers between 1939 and 1992 indicate a significant decrease in freshwater flow during this period (Stoker et al. 1996), potentially contributing to the increase of mangroves in Hillsborough Bay.

In Tampa Bay, the two primary objectives for utilizing thin layer placement as a marsh restoration strategy include (1) increasing marsh area and (2) increasing the resilience of the existing marshes to subsidence, sea level rise, and mangrove conversion. The first objective could be achieved by placing a layer of sediment in shallow water adjacent to existing marshes to increase the area of the marsh. The site location of this type of project would require consideration of surrounding seagrass habitat. The design of the project should take into account the desired future range of both marshes and seagrasses in the project area. The second objective would involve depositing material in a thin layer over existing marsh habitats. Thin layer open-water placement of material, similar to what is done in Mobile Bay, is not currently proposed as a strategy for Tampa Bay; however, it is an available option should stakeholders identify a need for this type of placement in the future.

\subsection{Sediment requirements}

As discussed in Section 11.1, a variety of sediment types ranging from sands to heavy clays and organic sediments can be utilized for spray disposal. No type of rock would be ideal for this type of placement. Siltier materials would require the use of more turbidity control measures and should be monitored to ensure there are no water quality concerns during construction.

\subsection{Construction methods}

Thin layer placement operations can be modified to target specific sites and to avoid sensitive habitats (Ray 2007). Material is typically slurried and placed in thickness ranging from a few centimeters to a foot. 
Decisions regarding sediment thickness should consider the species present, as there is considerable variation in the tolerance of different seagrass species to sedimentation (Erftemeijer and Lewis 2006). Previous studies indicate that water from the slurry rapidly drains off, leaving the deposited sediment without producing high levels of turbidity (Cahoon and Cowan 1988); however, turbidity control is a primary concern expressed by regulatory agencies.

At the New Jersey Avalon Pilot Project, a variety of coir logs in different diameters were used to contain dredged materials during marsh construction. The strategy was to build the sites to specific elevations that were controlled by the various diameters of the coir logs. The coir logs controlled the flows during pumping operations, considerably reducing runoff and turbidity. Other projects in the USACE Philadelphia District used turbidity curtains for marsh restoration projects located near open water. This method worked extremely well for reducing turbidity during placement ${ }^{1}$.

\subsection{Restoration costs}

\subsubsection{Dredging}

Dredging costs for longshore bars would be comparable to costs outlined for other placement methodologies at approximately $\$ 18 / \mathrm{cy}$, which includes transportation up to 10 miles from the dredge site.

- Cost: $\$ 18 /$ cy

\subsubsection{Material transport}

As discussed for other placement options, transporting material over 10 miles would cost an additional $\$ 1 /$ cy/additional mile.

- Cost: $\$ 1 /$ cy/additional mile (over 10 miles)

\subsubsection{Turbidity control}

Costs for turbidity control associated with thin layer placement would be similar to those described in Section 8.4.3 for Dredged Hole filling, and

\footnotetext{
1 Monica Chasten, U.S. Army Corps of Engineers, Philadelphia District (NAP), personal communication, 15 March 2017.
} 
Section 10.4.3 for Longshore Bar creation. Placing hay or pine straw bales in a pyramid of three is estimated to cost $\$ 8 /$ lin $\mathrm{ft}$. Depending on resource agency comments, additional turbidity control measures such as Type 1 turbidity curtains may not be necessary or required. In addition, it may be sufficient to install hay bales on the seaward side of the bar feature rather than on both sides, substantially reducing costs.

- Turbidity curtains (Type 1 ): $\$ 50 /$ lin $\mathrm{ft}$

- Hay bales: $\$ 3 /$ lin $\mathrm{ft}$ (one level)

\subsubsection{Other considerations}

Similar to longshore bar restoration, thin layer placement requires a relatively small amount of material. For example, placement of material at a thickness of $1 \mathrm{ft}$ over 20 acres requires approximately 32,000 cy of sediment. This sediment volume is much smaller than is typically dredged during a maintenance event for Tampa or Manatee Harbors. A dredging contractor may need to utilize multiple types of equipment to change placement locations from thin layer to upland, which would substantially increase costs. This type of restoration opportunity may be ideal for dredging the GIWW. Thin layer placement options are more suited to smaller volumes of dredged material. Because shoaling occurs slowly in the GIWW, sediment volumes are typically small. In addition, placement options are limited along the GIWW due to its infrequent dredging, and there are no actively maintained upland disposal sites along the waterway. However, it is important that potential marsh restoration projects requiring dredged materials are scoped and ready for placement when funding becomes available for maintenance dredging.

If an additional mobilization were required, the associated cost is anticipated to add approximately $\$ 150,000$ to the contract.

- Additional mobilization: $\$ 150,000$ 


\section{Conclusions}

More study is necessary to fully understand the ongoing conversion of habitats within Tampa Bay and the role that beneficial sediments may play within the variety of restoration projects. For example, data gaps exist with respect to sediment compatibility for the various types of habitat restoration. While some restoration could be constructed with a wider range of sediment types with limited impact on their eventual success, other habitats may require a narrower range of sediment types that would be difficult to guarantee from maintenance materials without extensive pre-construction sediment sampling.

In addition, while thin layer placement may eventually be a valuable method for environmental managers in Tampa Bay, it will be important to develop methods for restoring marsh habitats while recognizing and preserving the value of the mangrove habitats that are currently replacing them. Additional research is also required on tidal flats in the Tampa Bay area to identify habitat coverage goals and on the preferred methods that should be used to reach those goals. If restoration of tidal flat habitat were identified to be appropriate, it will need to be determined whether it is also appropriate to use dredged materials to construct this type of habitat.

Finally, RSM opportunities require stakeholders and sponsors in the local community to work with the USACE to overcome concerns such as outyear monitoring and costs above the least-cost placement option. Broad consensus within the environmental community and among stakeholders of the region's most critical restoration needs is extremely beneficial in moving projects forward, especially for projects that are highly visible to the public. 


\section{References}

Armitage, A. R., W. E. Highfield, S. D. Brody, and P. Louchouarn. 2015. "The Contribution of Mangrove Expansion to Salt Marsh Loss on the Texas Gulf Coast." PLOS ONE 10(5): e0125404.

Bolam, S. G., H. L. Rees, P. Somerfield, R. Smith, K. R. Clarke, R. M. Warwick, and E. Garnacho. 2006. "Ecological Consequences of Dredged Material Disposal in the Marine Environment: A Holistic Assessment of Activities around the England and Wales Coastline." Marine Pollution Bulletin 52(4): 415-426.

Cahoon, D. R., and J. H. Cowan, Jr. 1988. "Environmental Impacts and Regulatory Policy Implications of Spray Disposal of Dredged Material in Louisiana Wetlands." Coastal Management 16(4): 341-362.

Cahoon, D. R., D. J. Reed, and J. W. Day. 1995. "Estimating Shallow Subsidence in Microtidal Salt Marshes of the Southeastern United States: Kaye and Barghoorn Revisited." Marine Geology 128(1-2): 1-9.

Chasten, M., and K. Goldberg. 2016. Recent Experience with Channel Dredging and Placement to Restore Wetlands in New Jersey. U.S. Army Corps of Engineers.

Cross, L. 2013. Experimental Restoration of Longshore Bars Associated with Seagrass Recovery in Tampa Bay, Florida, USA. Final Report submitted to The Gulf of Mexico Program in partial fulfillment of grant ID \#MX-96448506-o.

Erftemeijer, P. L., and R. R. Lewis. 2006. "Environmental Impacts of Dredging on Seagrasses: A Review.” Marine Pollution Bulletin 52(12): 1553-1572.

Greening, H., L. Cross, and E. Sherwood. 2011. "A Multiscale Approach to Seagrass Recovery in Tampa Bay, Florida.” Ecological Restoration 29(1-2): 82-93.

Lewis, R. R. 2005. Historical Longshore Bar Mapping, Tampa Bay, Florida. Prepared by Roy R. Lewis, III, Coastal Resources Group, Inc.

Lewis, R. R., M. J. Durako, M. D. Moffler, and R. C. Phillips. 1985. "Seagrass Meadows in Tampa Bay - A Review.” Edited by S. F. Treat, J. L. Simon, R. R. Lewis, and R. L. Whitman, Jr., 210-246. Proceedings, Tampa Bay Area Scientific Information Symposium, May 1982. Minneapolis, MN: Burgess Publishing Company.

Lewis, R. R., and E. Estevez. 1988. The Ecology of Tampa Bay, Florida: An Estuarine Profile. U.S. Fish and Wildlife Service Biological Report 85(7.18). Washington, DC: Department of the Interior, U.S. Fish and Wildlife Service, Research and Development, National Wetlands Research Center.

Lillycrop, L. S., J. D. Rosati, J. M. Wozencraft, and R. Dopsovic. 2011. “Advancement of Technologies for Practicing Regional Sediment Management.” Proceedings, Coastal Sediments Conference 2011. Miami, FL.

Parson, L., N. Lovelace, E. Godsey, K. Reine, and J. Gailani. 2015. Regional Sediment Management (RSM) Strategy for Mobile Bay, Alabama. ERDC/CHL CHETNXIV-41. Vicksburg, MS: U.S. Army Engineer Research and Development Center. 
PBS\&J. 2010. Tampa Bay Estuary Program Habitat Master Plan Update. Technical Publication 06-09. St. Petersburg, FL.

Pezeshki, S. R., R. D. DeLaune, and J. H. Pardue. 1992. "Sediment Addition Enhances Transpiration and Growth of Spartina alterniflora in Deteriorating Louisiana Gulf Coast Salt Marshes.” Wetlands Ecology and Management 1(4): 185-189.

Raabe, E. A., and L. Gauron. 2007. "Historic Records Shed Light on Marsh to Mangrove Change in Tidal Wetlands." 19th Biennial Conference of the Estuarine Research Federation. Providence, RI.

Raabe, E. A., L. C. Roy, and C. C. McIvor. 2012. "Tampa Bay Coastal Wetlands: Nineteenth to Twentieth Century Tidal Marsh-to-Mangrove Conversion.” Estuaries and Coasts 35(5): 1145-1162.

Ray, G. 2007. Thin Layer Placement of Dredged Material on Coastal Wetlands: A Review of the Technical and Scientific Literature. ERDC/EL TN-07-1. Vicksburg, MS: U.S. Army Engineer Research and Development Center.

Sherwood, E. T., H. S. Greening, J.R. Johansson, K. Kaufman, and G. E. Raulerson. 2017. "Tampa Bay (Florida, USA): Documenting Seagrass Recovery since the 1980's and Reviewing the Benefits." Southeastern Geographer 57(3): 294-319.

Stoker, Y. E., V. A. Levesque, and W. M. Woodham. 1996. The Effect of Discharge and Water Quality of the Alafia River, Hillsborough River, and the Tampa Bypass Canal on Nutrient Loading to Hillsborough Bay, Florida. Water Resources Investigation Report 95-4107. Reston, VA: U.S. Geological Survey.

Tampa Bay Estuary Program (TBEP). 2005. Tampa Bay Dredged Hole Habitat Assessment Project; Final Report to the U.S. Environmental Protection Agency Region 4. Technical Publication 04-05. Tampa, FL: Tampa Bay Dredged Hole Habitat Assessment Advisory Team. Washington, DC: USEPA.

U.S. Congress. 1972. Marine Protection, Research, and Sanctuaries Act. 16 USC, 1431 et seq. and 33 USC, 1401 et seq. (1988).

U.S. Environmental Protection Agency (USEPA). 2009. Technical Memorandum; 2009 Tampa Berm ODMDS Habitat Assessment. Technical Memorandum to Gary Collins, USACE ODMDS Site Manager, from Jed G. Campbell, Research Aquatic Biologist, Gulf Ecology Division, U.S. Environmental Protection Agency. 
The public reporting burden for this collection of information is estimated to average 1 hour per response, including the time for reviewing instructions, searching existing data sources, gathering and maintaining the data needed, and completing and reviewing the collection of information. Send comments regarding this burden estimate or any other aspect of this collection of information, including suggestions for reducing the burden, to Department of Defense, Washington Headquarters Services, Directorate for Information Operations and Reports (0704-0188), 1215 Jefferson Davis Highway, Suite 1204, Arlington, VA 22202-4302. Respondents should be aware that notwithstanding any other provision of law, no person shall be subject to any penalty for failing to comply with a collection of information if it does not display a currently valid OMB control number.

PLEASE DO NOT RETURN YOUR FORM TO THE ABOVE ADDRESS.

\begin{tabular}{|l|l|l}
\hline 1. REPORT DATE & 2. REPORT TYPE & 3. DATES COVERED (FrOm - To)
\end{tabular}

May 2019

Final Report

\section{TITLE AND SUBTITLE}

A Review of RSM Implementation Strategies and Recommendations for Ecosystem

Restoration in Tampa Bay, Florida

\section{5a. CONTRACT NUMBER}

5b. GRANT NUMBER

5c. PROGRAM ELEMENT NUMBER

5d. PROJECT NUMBER

476925

5e. TASK NUMBER

5f. WORK UNIT NUMBER

8. PERFORMING

ORGANIZATION REPORT NUMBER

Coastal and Hydraulics Laboratory

3909 Halls Ferry Road

Vicksburg, MS 39180-6199

ERDC/CHL TR-19-7

\section{SPONSORING/MONITORING AGENCY NAME(S) AND ADDRESS(ES)}

U.S. Army Corps of Engineers

Washington, DC 20314-1000

10. SPONSOR/MONITOR'S ACRONYM(S)

HQUSACE

\section{SPONSOR/MONITOR'S} REPORT NUMBER(S)

\section{DISTRIBUTION/AVAILABILITY STATEMENT}

Approved for public release; distribution is unlimited.

\section{SUPPLEMENTARY NOTES}

\section{ABSTRACT}

Regional Sediment Management (RSM) is a systems approach using best management practices for more efficient and effective use of sediments in coastal, estuarine, and inland environments. The primary RSM objective for this Tampa Bay study is to determine what opportunities exist to beneficially use dredged material for ecosystem restoration and habitat enhancement. A secondary objective is to ensure more efficient use of federal funds by coordinating dredging schedules for navigation and storm damage reduction projects with federal, state, and local authorities. This study met these objectives through collaboration with stakeholders on the technical, social, and cultural components required to combine resources to meet common goals.

The Federal Standard for navigation projects in the Tampa Bay region is either upland disposal or disposal at the Tampa Bay Ocean Dredged Material Disposal Site. This document describes six ecosystem restoration placement strategies: (1) beach nourishment, (2) nearshore placement, (3) dredged hole filling, (4) island creation/stabilization, (5) longshore bars, and (6) thin layer placement. Dredged material from navigation projects throughout Tampa Bay were considered, including Tampa Harbor, Manatee Harbor, St. Petersburg Harbor, and the Gulf Intracoastal Waterway. For each placement strategy, the document outlines the required sediments, volumes, construction methodologies, and estimated costs.

\section{SUBJECT TERMS}

Littoral drift, Restoration ecology, Sedimentation and deposition, Sediment transport, Tampa Bay (Fla.)

16. SECURITY CLASSIFICATION OF:

a. REPORT b. ABSTRACT

Unclassified
Unclassified

\section{LIMITATION OF} ABSTRACT

SAR

\section{c. THIS PAGE}

Unclassified
18. NUMBER OF PAGES

66 19a. NAME OF RESPONSIBLE PERSON

19b. TELEPHONE NUMBER (Include area code) 904-232-2136 